\title{
Criação de um Sistema de Previsão e Alerta de Riscos a deslizamentos e enchentes, visando minimizar os impactos sócio-ambientais no bairro Quitandinha, bacia do rio Piabanha (afluente do Paraíba do Sul), município de Petrópolis-RJ.
}

\author{
Antônio José Teixeira Guerra \\ Marcos Barreto de Mendonça \\ Patrícia Batista Melo Lopes \\ Fabio da Silva Lima \\ Maria do Carmo Oliveira Jorge \\ Bruno da Rocha Mendes
}

\section{INTRODUÇÃO}

O presente artigo refere-se à criação de um Sistema de Previsão e Alerta de Riscos, cuja finalidade é monitorar os riscos de deslizamentos e de enchentes, que ocorrem no município de Petrópolis. Esse trabalho pode ser de grande relevância para a Defesa Civil, no sentido de poder atuar preventivamente e, consequentemente, minimizar os impactos, entre eles, os danos sócio-ambientais, tão típicos desse município, em especial, durante as chuvas que ocorrem nos meses do verão.

Nas últimas décadas Petrópolis vem passando por centenas de eventos catastróficos, muitas vezes associados à perda de vidas humanas, bem como da destruição de casas, ruas, pontes e bens materiais de um modo geral (Guerra et al., 2007; Guerra e Lopes, 2009; Gonçalves e Guerra, 2009). Pelo município possuir uma extensão grande, nesse primeiro estágio, optou-se por trabalhar apenas no bairro do Quitandinha, onde tem acontecido, com maior freqüência, enchentes e movimentos de massa. Outro fator pela escolha do bairro Quitandinha é a localização da estação meteorológica do LNCC (Laboratório Nacional de Computação Científica), situada nesse bairro, e que forneceu os dados de pluviosidade, para o período estudado. Garante-se, assim, uma boa representatividade desses dados para a área de trabalho. Dessa forma, os dados que serão aqui apresentados, referem-se a um projeto piloto, onde está sendo testada a metodologia criada, especialmente para esse projeto. 
A partir dos dados de ocorrência de acidentes fornecidos pela Coordenadoria de Defesa Civil da Prefeitura Municipal de Petrópolis e dos dados de pluviosidade fornecidos pelo LNCC para o período situado entre 2003 e 2009 foi possível elaborar uma série histórica de todos os eventos referentes a deslizamentos e enchentes da áreapiloto (Bairro do Quitandinha).

O referido trabalho também constou da execução de vistorias de diversos setores do bairro do Quitandinha, onde foram levantadas uma série de variáveis ambientais e sócio-econômicas, com o objetivo de classificar sub-áreas, com relação aos fatores de vulnerabilidade a deslizamentos e a enchentes.

\subsection{Objetivos}

O trabalho tem como objetivo principal o desenvolvimento de um projeto piloto para a construção de um Sistema de Previsão e Alerta de Riscos de enchentes e escorregamentos de encostas, no município de Petrópolis, visando minimizar os impactos sócio-ambientais resultantes desses eventos catastróficos.

\subsection{Características da área de estudo}

A área de estudo se situa na Região das Escarpas e Reversos da Serra do Mar, inserida em uma das quatro unidades que compõem esta região, a Unidade Geomorfológica da Serra dos Órgãos (RADAM, 1983).

Esta região apresenta um quadro morfológico relacionado aos efeitos de um tectonismo regional e de sucessivas fases erosionais. Trata-se de uma área resultante de dobramentos, reativações de falhas e remobilização de blocos. A topografia reflete esses condicionamentos geológicos predominantes e em toda a sua extensão são registrados vales alongados, segmentos de drenagem retilíneos, maciços graníticos, linhas de cristas e cumeadas paralelas, relevos com grandes desníveis altimétricos, escarpas íngremes e alvéolos intermontanos. 
Os estudos sobre os deslizamentos de terra não são significativos apenas para as cidades situadas no planalto cristalino, como os casos de Petrópolis, Teresópolis, Angra dos Reis, Caraguatatuba e Rio de Janeiro, mas também para todas as áreas urbanizadas que englobam diversos tipos de encostas. O desenvolvimento dos estudos e mapeamentos geotécnicos vem oferecendo informações e documentos valiosos para a compreensão da dinâmica geomorfológica em áreas urbanizadas (Selby, 1993; Christofoletti, 2001).

A ampliação de áreas urbanizadas, devido à construção de áreas impermeabilizadas, repercute na capacidade de infiltração das águas no solo, favorecendo o escoamento superficial e a concentração das enxurradas. A urbanização afeta o funcionamento do ciclo hidrológico, pois interfere no rearranjo do armazenamento e na trajetória das águas.

Apesar dos fenômenos de chuvas de forte intensidade e escorregamentos serem mais propensos nas regiões tropicais, o aumento da ocupação de áreas pelas atividades antrópicas, desencadeia reações, que associadas ao mau uso, manejo e conservação dos solos, vêm gerando problemas ambientais, principalmente em áreas de topografia acidentada (Mendonça e Guerra, 1997, Gonçalves e Guerra, 2009), como ocorre no bairro do Quitandinha.

O desencadeamento de escorregamentos em uma dada região depende de várias condicionantes naturais, porém, a chuva é um dos fatores mais significativos, pois quase todos os registros estão associados a episódios de chuvas de forte intensidade, ou de períodos prolongados, geralmente concentrados em alguns meses, o que é muito comum em Petrópolis. Os condicionantes naturais podem, juntamente com o manejo inadequado, acelerar a degradação. Chuvas concentradas, encostas desprotegidas de vegetação, contato solo-rocha abrupto, descontinuidades litológicas, geomorfológicas e pedológicas, declividade das encostas são algumas das condições que podem acelerar os processos erosivos e movimentos de massa (Cunha e Guerra, 2006). Vários desses fatores podem ser observados nas áreas vistoriadas no Quitandinha.

Especificamente no caso do Quitandinha, a desestabilização das encostas, feita pela construção de casas populares e condomínios, tem provocado o desencadeamento de uma série de problemas sócio-ambientais, principalmente quando não existe uma legislação urbanística em sintonia com as limitações físicas, ou quando, apesar de sua existência, ela não consegue ser colocada em prática de forma eficaz, como é o caso da área urbana aqui mencionada.

Essa ocupação irregular é uma das variáveis responsáveis pelo aumento gradual dos movimentos de massa que tem ocorrido no Quitandinha, que aliada ao desmatamento e a 
ocupação desordenada, coloca em sério risco a população de assentamentos precários em encostas do município (Mendonça e Temóteo, 1993), entre as quais ressalta-se o bairro do Quitandinha.

No que diz respeito ao clima, Petrópolis é caracterizado como tropical de altitude, com excedente hídrico no decorrer de todo o ano, principalmente no verão. Predominam temperaturas amenas e chuvas bem distribuídas durante todo o ano, sem apresentar estação seca. Nos meses de verão ocorre a concentração dos maiores índices pluviométricos e, assim o IBGE classifica o clima do município como Mesotérmico Brando.

Os dados pluviométricos fornecem informações importantes sobre a pluviosidade diária e mensal de determinada área, que juntamente com as informações sobre declividade, aspectos geotécnicos, aspectos antrópicos, cobertura vegetal, etc, auxiliam na identificação das áreas mais propensas à ocorrência de deslizamentos de terra.

Para caracterizar o índice pluviométrico da região, foram utilizados os dados do pluviômetro instalado no LNCC, localizado nas seguintes coordenadas geográficas: latitude $22^{\circ} 31^{\prime} 43^{\prime \prime} \mathrm{S}$ e longitude $43^{\circ} 12^{\prime} 45^{\prime \prime} \mathrm{W}$, altitude de $864,5 \mathrm{~m}$.

\subsection{Mapa de localização}

Esse mapa retrata bem o local da área de estudo, não só em relação ao município de Petrópolis e ao estado do Rio de Janeiro, como também o próprio bairro do Quitandinha, onde o estudo foi feito (Figura 1). 

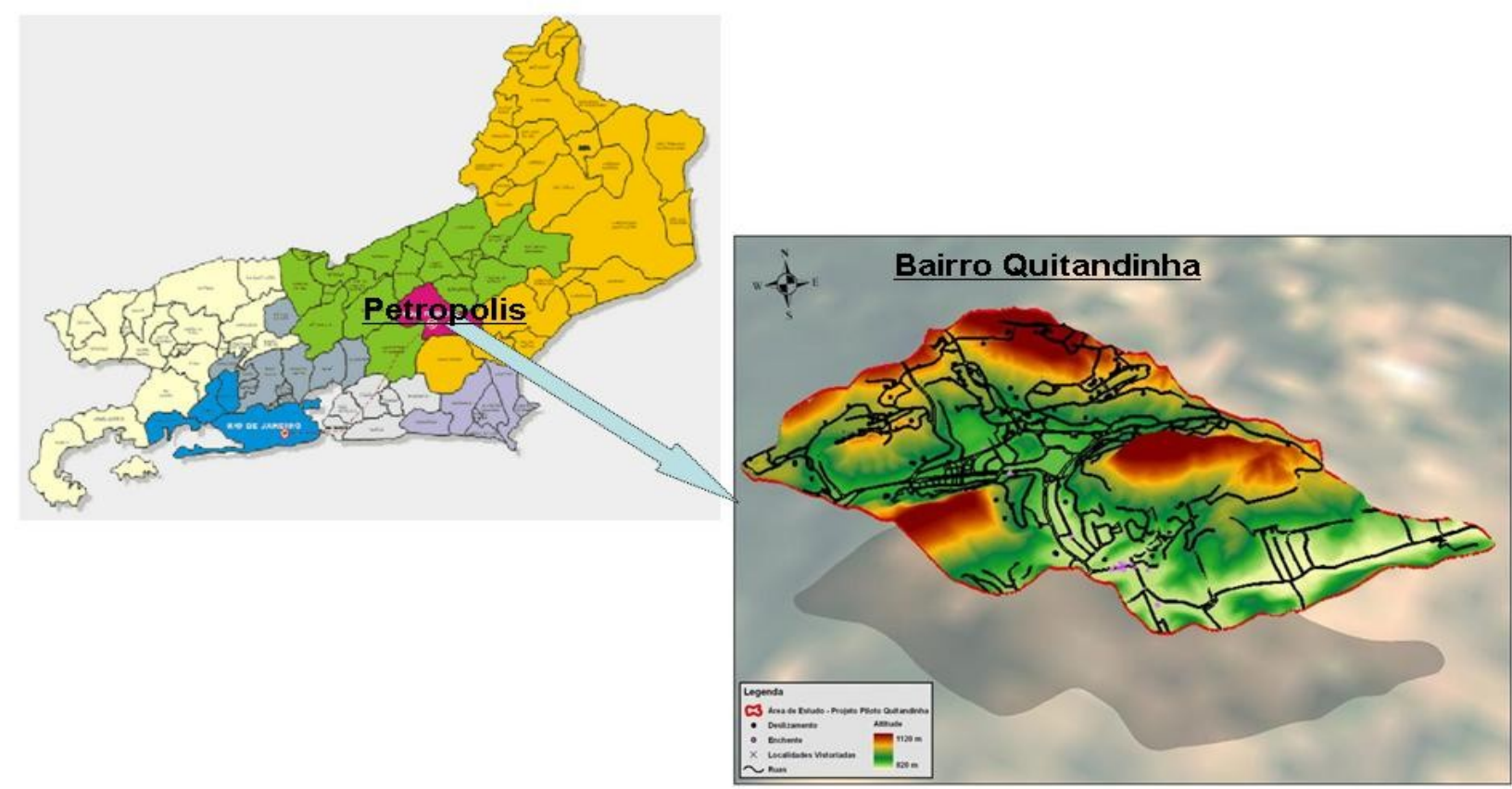

Figura 1. Mapa de localização da área de estudo.

\section{METODOLOGIA}

Um Plano Preventivo de Defesa Civil (PPDC) tem a finalidade de promover a remoção, para locais seguros, dos moradores em situação de risco e com a expectativa de iminência do acidente. E, após passada a fase emergencial, decide-se, caso seja possível, pelo retorno da população removida.

Para a implantação de um PPDC é preciso elaborar um Sistema de Alerta, baseando-se na probabilidade de ocorrência de acidentes geológicos, em função da pluviosidade ocorrida e da prevista. A pluviosidade necessária para a ocorrência de eventos de deslizamentos e inundações pode variar de região para região, de acordo com os condicionantes naturais e antrópicos de cada uma. 
Portanto é necessário um estudo para a determinação de índices de pluviosidade críticos para as comunidades com maiores suscetibilidades aos eventos de deslizamentos e enchentes no Município de Petrópolis.

O objetivo geral desse artigo é determinar os níveis de índices pluviométricos necessários para a deflagração de eventos de deslizamentos e enchentes no bairro do Quitandinha e que seja possível, no futuro, extrapolarmos a metodologia para o município como um todo. Esses níveis serão estimados a partir de análises dos dados históricos disponíveis da ocorrência desses eventos e dos respectivos índices pluviométricos. O cruzamentos desses dados possibilitará a estimativa de índices pluviométricos que indicará uma grande probabilidade de ocorrência de eventos de deslizamentos.

Esses índices pluviométricos críticos deverão ser ajustados durante a operação do Protótipo do Sistema de Alerta, a partir das futuras análises, correlacionando os dados obtidos pela rede de pluviômetros e linímetros e os futuros eventos registrados.

O Sistema de Alerta permitirá a otimização do trabalho da Defesa Civil em informar à população, em tempo hábil, sobre a expectativa da ocorrência de acidentes geológicos e/ou remover os moradores de forma preventiva e temporária.

A metodologia para alcançar esse objetivo consiste nas seguintes etapas:

A - Delimitação da região representada pela estação meteorológica do LNCC, onde está instalado o pluviômetro.

B - Identificação e caracterização da áreas de risco associados a deslizamentos ou enchentes no Quitandinha. O nível de risco de cada área foi definido a partir de fatores de vulnerabilidade que dependem de uma série de condicionantes naturais e antrópicos. Para a quantificação dos níveis de risco foram elaboradas tabelas de fatores de vulnerabilidade a enchentes (Tabela 1) e a deslizamentos (Tabela 2). O nível de cada fator de vulnerabilidade foi definido a partir de vistorias de campo através análises tácteis-visuais e de coletas de informações, durante essas vistorias. Para cada região vistoriada, foi definido um nível de risco, podendo ser Muito Alto, Alto, Médio e Baixo;

C-Coleta de dados históricos de eventos de deslizamento e inundações, junto à Defesa Civil de Petrópolis; 
D- Coleta de dados históricos de índices pluviométricos, junto ao LNCC, para o período de 2003 a 2009;

E - Cruzamento dos dados de ocorrência de eventos com o dados de pluviometria para a definição de um índice crítico para toda a região em estudo;

F - Definição de índices críticos para a área de risco estudo dentro da região em estudo (Quitandinha).

Tabela 1 - Fatores de Vulnerabilidade a enchentes

\begin{tabular}{|c|c|c|c|c|c|}
\hline $\begin{array}{l}\text { Fatores de } \\
\text { Vulnerabilidade } \\
\text { para Enchentes }\end{array}$ & Nível 1 & Nível 2 & Nível 3 & Nível 4 & Nível 5 \\
\hline $\begin{array}{l}\text { Drenagem natural } \\
\text { (quantidade de } \\
\text { canais) }\end{array}$ & $\begin{array}{c}\text { Fundo de } \\
\text { vale que } \\
\text { não recebe } \\
\text { nenhuma } \\
\text { contribuição } \\
\text { de canais de }\end{array}$ & $\begin{array}{l}\text { Local que recebe pouca } \\
\text { contribuição de canais de } \\
\text { drenagem }\end{array}$ & $\begin{array}{l}\text { Local que recebe } \\
\text { contribuição de } \\
\text { canais de } \\
\text { drenagem maior }\end{array}$ & $\begin{array}{l}\text { Local situado } \\
\text { nos flancos dos } \\
\text { canais de } \\
\text { drenagem }\end{array}$ & $\begin{array}{l}\text { Local situado dentro } \\
\text { de um talvegue ou } \\
\text { canal de drenagem } \\
\text { (canal de } 1^{\mathrm{a}} \text { ordem). }\end{array}$ \\
\hline $\begin{array}{c}\text { Lançamento de } \\
\text { detritos } \\
\text { (lixo/entulho) dentro } \\
\text { ou nas margens dos } \\
\text { rios }\end{array}$ & $\begin{array}{l}\text { Ausência de } \\
\text { lançamento } \\
\text { de detritos }\end{array}$ & $\begin{array}{l}\text { Presença de pequena } \\
\text { quantidade de detritos }\end{array}$ & $\begin{array}{l}\text { Presença de } \\
\text { razoável } \\
\text { quantidade de } \\
\text { detritos }\end{array}$ & $\begin{array}{c}\text { Presença de } \\
\text { grande } \\
\text { quantidade de } \\
\text { detritos } \\
\text { jogados a } \\
\text { intervalos } \\
\end{array}$ & $\begin{array}{l}\text { Presença de grandes } \\
\text { quantidades de } \\
\text { detritos despejadas } \\
\text { frequentemente }\end{array}$ \\
\hline Cobertura vegetal & $\begin{array}{c}\text { Floresta } \\
\text { densa e } \\
\text { estabilizada }\end{array}$ & $\begin{array}{l}\text { Árvores de médio porte e bem } \\
\text { concentradas }\end{array}$ & $\begin{array}{c}\text { Árvores de } \\
\text { pequeno porte e } \\
\text { bem espaçadas } \\
\text { com capim }\end{array}$ & Capim & Solo exposto \\
\hline $\begin{array}{c}\text { Impermeabilização } \\
\text { das margens (\% de } \\
\text { ocupação das } \\
\text { margens) }\end{array}$ & 0 a $20 \%$ & 21 a $40 \%$ & 41 a $60 \%$ & 61 a $80 \%$ & Acima de $81 \%$ \\
\hline $\begin{array}{c}\text { Grau de } \\
\text { assoreamento dos } \\
\text { canais por } \\
\text { sedimentos }\end{array}$ & $\begin{array}{c}\text { Não } \\
\text { assoreado }\end{array}$ & Pouco assoreado & $\begin{array}{l}\text { Moderadamente } \\
\text { assoreado }\end{array}$ & $\begin{array}{c}\text { Muito } \\
\text { assoreado }\end{array}$ & $\begin{array}{l}\text { Extremamente } \\
\text { assoreado }\end{array}$ \\
\hline $\begin{array}{c}\text { Impermeabilização } \\
\text { das encostas } \\
\text { contribuintes }\end{array}$ & 0 a $10 \%$ & 11 a $25 \%$ & 26 a $35 \%$ & 36 a $45 \%$ & Acima de $45 \%$ \\
\hline $\begin{array}{l}\text { Drenagem em } \\
\text { direção ao rio } \\
\text { principal }\end{array}$ & $\begin{array}{l}\text { Escoamento } \\
\text { na direção } \\
\text { contrária ao } \\
\text { rio principal }\end{array}$ & $\begin{array}{l}\text { Ruas pouco asfaltadas com } \\
\text { fluxo de águas em direção ao } \\
\text { rio principal }\end{array}$ & $\begin{array}{c}\text { Ruas } \\
\text { razoavelmente } \\
\text { asfaltadas com } \\
\text { drenagem em } \\
\text { direção ao rio } \\
\text { principal } \\
\end{array}$ & $\begin{array}{c}\text { Ruas muito } \\
\text { asfaltadas ou } \\
\text { de } \\
\text { paralelepípedos } \\
\text { com drenagem } \\
\text { em direção ao } \\
\end{array}$ & $\begin{array}{c}\text { Ruas totalmente } \\
\text { asfaltadas } \\
\text { (impermeabilizadas) } \\
\text { com drenagem em } \\
\text { direção ao rio } \\
\text { principal } \\
\end{array}$ \\
\hline
\end{tabular}




\begin{tabular}{|c|c|c|c|c|c|c|}
\hline $\begin{array}{c}\text { Fatores de } \\
\text { Vulnerabilidade } \\
\text { para } \\
\text { Deslizamentos de } \\
\text { Terra } \\
\end{array}$ & NA & Nível 1 & Nível 2 & Nível 3 & Nível 4 & Nível 5 \\
\hline $\begin{array}{c}\text { Declividade } \\
\text { (medida em graus) }\end{array}$ & & $1^{\circ}-10^{\circ}$ & $11^{\circ}-20^{\circ}$ & $21^{\circ}$ a $30^{\circ}$ & $31^{\circ}$ a $41^{\circ}$ & Acima de $41^{\circ}$ \\
\hline $\begin{array}{l}\text { Drenagem natural } \\
\text { (quantidade de } \\
\text { canais) }\end{array}$ & & $\begin{array}{l}\text { Local que não } \\
\text { recebe nenhuma } \\
\text { contribuição de } \\
\text { canais de } \\
\text { drenagem }\end{array}$ & $\begin{array}{l}\text { Local que recebe } \\
\text { pouca contribuição } \\
\text { de canais de } \\
\text { drenagem }\end{array}$ & $\begin{array}{c}\text { Local que recebe } \\
\text { contribuição de } \\
\text { canais de } \\
\text { drenagem maior e } \\
\text { com surgência de } \\
\text { água } \\
\end{array}$ & $\begin{array}{l}\text { Local situado nos } \\
\text { flancos dos canais } \\
\text { de drenagem }\end{array}$ & $\begin{array}{l}\text { Local situado } \\
\text { dentro de um } \\
\text { canal de } \\
\text { drenagem } \\
\text { (canal de } 1^{\mathrm{a}} \\
\text { ordem } \\
\end{array}$ \\
\hline $\begin{array}{l}\text { Rede de esgoto } \\
\text { sanitário }\end{array}$ & & $\begin{array}{l}\text { Rede de esgoto de } \\
\text { boa qualidade e } \\
\text { bem distribuídas } \\
\text { espacialmente } \\
\end{array}$ & $\begin{array}{l}\text { Rede de esgoto } \\
\text { com problemas de } \\
\text { vazamento }\end{array}$ & $\begin{array}{l}\text { Presença de fossa } \\
\text { e rede de esgoto } \\
\text { com vazamento }\end{array}$ & $\begin{array}{l}80 \% \text { fossae } / \mathrm{ou} \\
\text { sumidouro }\end{array}$ & $\begin{array}{l}\text { Presença de } \\
\text { valas à céu } \\
\text { aberto }\end{array}$ \\
\hline $\begin{array}{c}\text { Rede de águas } \\
\text { pluviais }\end{array}$ & & $\begin{array}{l}\text { Rede de águas } \\
\text { pluviais com um } \\
\text { grande número de } \\
\text { bueiros/canaletas } \\
\text { e com boa } \\
\text { distribuição } \\
\text { espacial e limpos }\end{array}$ & $\begin{array}{l}\text { Rede de águas } \\
\text { pluviais com } \\
\text { quantidade } \\
\text { razoável de } \\
\text { bueiros/canaletas e } \\
\text { com distribuição } \\
\text { espacial regular }\end{array}$ & $\begin{array}{c}\text { Presença de } \\
\text { bueiros/canaletas } \\
\text { mal distribuídos, } \\
\text { que não são } \\
\text { suficientes para a } \\
\text { vazão do } \\
\text { escoamento da } \\
\text { água } \\
\end{array}$ & $\begin{array}{l}\text { Presença de } \\
\text { bueiros mal } \\
\text { distribuídos e } \\
\text { frequentemente } \\
\text { entupidos e/ou } \\
\text { canaletas } \\
\text { quebradas }\end{array}$ & $\begin{array}{c}\text { Ausência de } \\
\text { bueiros/canaleta } \\
\text { s, canaletas } \\
\text { quebradas e/ou } \\
\text { canaletas com } \\
\text { destino final na } \\
\text { própria encosta }\end{array}$ \\
\hline $\begin{array}{l}\text { Abastecimento de } \\
\text { água }\end{array}$ & & $\begin{array}{l}\text { Ótima qualidade } \\
\text { das tubulações e } \\
\text { ausência de } \\
\text { vazamentos }\end{array}$ & $\begin{array}{l}\text { Baixo nível de } \\
\text { vazamentos e em } \\
\text { poucos lugares }\end{array}$ & $\begin{array}{l}\text { Médio nível de } \\
\text { vazamentos e bem } \\
\text { distribuídos pela } \\
\text { região }\end{array}$ & $\begin{array}{c}\text { Alto nível de } \\
\text { vazamentos das } \\
\text { tubulações e } \\
\text { distribuídas por } \\
\text { toda a área } \\
\end{array}$ & $\begin{array}{c}\text { Ausência total } \\
\text { de } \\
\text { abastecimento } \\
\text { de água oficial }\end{array}$ \\
\hline $\begin{array}{l}\text { Lançamento de } \\
\text { detritos } \\
\text { (lixo/entulho) }\end{array}$ & & $\begin{array}{c}\text { Ausência de } \\
\text { lançamento de } \\
\text { detritos }\end{array}$ & $\begin{array}{c}\text { Presença de } \\
\text { pequena } \\
\text { quantidade de } \\
\text { detritos (espessura } \\
\text { de até } 0,50 \mathrm{~m}) \\
\text { localizada em } \\
\text { poucos lugares }\end{array}$ & $\begin{array}{c}\text { Presença de } \\
\text { razoável } \\
\text { quantidade de } \\
\text { detritos (espessura } \\
\text { acima de } 0,50 \mathrm{~m} \text { ) } \\
\text { distribuídas ao } \\
\text { redor da } \\
\text { ocorrência }\end{array}$ & $\begin{array}{c}\text { Presença de } \\
\text { grande quantidade } \\
\text { de detritos } \\
\text { (espessura acima } \\
\text { de } 1,0 \mathrm{~m} \text { ) jogados a } \\
\text { intervalos } \\
\text { regulares e nos } \\
\text { mesmos locais }\end{array}$ & $\begin{array}{c}\text { Presença de } \\
\text { grandes } \\
\text { quantidades de } \\
\text { detritos } \\
\text { (espessura } \\
\text { acima de } 1,0 \mathrm{~m} \text { ) } \\
\text { despejadas } \\
\text { frequentemente } \\
\text { ao redor da } \\
\text { ocorrência e } \\
\text { também nos } \\
\text { mesmos locais }\end{array}$ \\
\hline $\begin{array}{c}\text { Existência de } \\
\text { cortes e/ou aterros }\end{array}$ & & $\begin{array}{l}\text { Ausência de } \\
\text { cortes e/ou } \\
\text { aterros }\end{array}$ & $\begin{array}{l}\text { Cortes e/ou aterros } \\
\text { pequenos (até } \\
1,50 \mathrm{~m} \text { ) em pouca } \\
\text { quantidade e com } \\
\text { contenções }\end{array}$ & $\begin{array}{l}\text { Cortes e/ou aterros } \\
\text { maiores que o } \\
\text { anterior em } \\
\text { tamanho (acima de } \\
1,5 \mathrm{~m} \text { ) e em } \\
\text { quantidade e com } \\
\text { contenções }\end{array}$ & $\begin{array}{l}\text { Cortes e/ou aterros } \\
\text { (até } 1,50 \mathrm{~m} \text { ) sem } \\
\text { contenções }\end{array}$ & $\begin{array}{l}\text { Cortes e/ou } \\
\text { aterros maiores } \\
\text { que o anterior } \\
\text { (acima de } \\
1,50 \mathrm{~m}) \text { e sem } \\
\text { contenções }\end{array}$ \\
\hline $\begin{array}{l}\text { Existência de } \\
\text { obras de } \\
\text { estabilização }\end{array}$ & & $\begin{array}{l}\text { Presença de obras } \\
\text { de estabilização } \\
\text { de boa qualidade } \\
\text { e em bom estado, } \\
\text { sem rachaduras, } \\
\text { deformações ou } \\
\text { infiltrações }\end{array}$ & $\begin{array}{c}\text { Obras de } \\
\text { estabilização com } \\
\text { pequenas } \\
\text { rachaduras, em } \\
\text { poucos locais, com } \\
\text { baixa deficiência } \\
\text { da obra,com altura } \\
\text { até } 1,50 \mathrm{~m}\end{array}$ & $\begin{array}{c}\text { Obras de } \\
\text { estabilização, com } \\
\text { pequenas } \\
\text { rachaduras e } \\
\text { infiltrações } \\
\text { localizadas ao } \\
\text { longo da obra, } \\
\text { com média } \\
\text { deficiência e } \\
\text { altura acima de } \\
1,50 \mathrm{~m} \\
\end{array}$ & $\begin{array}{c}\text { Obras de } \\
\text { estabilização com } \\
\text { muitas rachaduras } \\
\text { e infiltrações } \\
\text { localizadas ao } \\
\text { longo de toda a } \\
\text { obra e com alta } \\
\text { deficiência da obra }\end{array}$ & $\begin{array}{c}\text { Ausência de } \\
\text { obras de } \\
\text { estabilização de } \\
\text { encostas em } \\
\text { áreas com } \\
\text { necessidade de } \\
\text { obras de } \\
\text { contenção }\end{array}$ \\
\hline Cobertura vegetal & & $\begin{array}{c}\text { Floresta densa e } \\
\text { estabilizada }\end{array}$ & $\begin{array}{l}\text { Árvores de médio } \\
\text { porte e bem } \\
\text { concentradas }\end{array}$ & $\begin{array}{c}\text { Árvores de } \\
\text { pequeno porte e } \\
\text { bem espaçadas }\end{array}$ & $\begin{array}{l}\text { Gramíneas, capim } \\
\text { e/ou arbustos }\end{array}$ & Solo exposto \\
\hline
\end{tabular}


Anais II Seminário de Recursos Hídricos da Bacia Hidrográfica do Paraíba do Sul: Recuperação de Áreas Degradadas, Serviços Ambientais e Sustentabilidade, Taubaté, Brasil, 09-11 dezembro 2009, IPABHi, p. 785-824.

(doi:10.4136/serhidro.103)

\begin{tabular}{|c|c|c|c|c|c|}
\hline $\begin{array}{c}\text { Existência de } \\
\text { matacões } \\
\text { (superficiais) }\end{array}$ & $\begin{array}{l}\text { Não há matacões } \\
\text { ao longo da } \\
\text { encosta }\end{array}$ & $\begin{array}{c}\text { Presença de } \\
\text { pequena } \\
\text { quantidade de } \\
\text { matacões e de } \\
\text { pequeno tamanho }\end{array}$ & $\begin{array}{l}\text { Presença de } \\
\text { matacões de porte } \\
\text { médio, em } \\
\text { quantidade } \\
\text { pequena e } \\
\text { concentrados em } \\
\text { poucos locais e } \\
\text { parcialmente } \\
\text { enterrados } \\
\end{array}$ & $\begin{array}{c}\text { Presença de } \\
\text { matacões de porte } \\
\text { médio, em grande } \\
\text { quantidade e } \\
\text { simplesmente } \\
\text { apoiados no } \\
\text { terreno em posição } \\
\text { medianamente } \\
\text { desfavorável }\end{array}$ & $\begin{array}{l}\text { Presença de } \\
\text { matacões } \\
\text { grandes, em } \\
\text { grande número } \\
\text { e em posições } \\
\text { bastante } \\
\text { desfavoráveis }\end{array}$ \\
\hline $\begin{array}{l}\text { Aspectos lito- } \\
\text { estruturais }\end{array}$ & $\begin{array}{l}\text { Rocha sã, sem } \\
\text { aspectos de } \\
\text { fraturas ou } \\
\text { rupturas }\end{array}$ & $\begin{array}{c}\text { Rocha com poucas } \\
\text { fraturas } \\
\text { localizadas, sem } \\
\text { risco aparente de } \\
\text { queda de blocos }\end{array}$ & $\begin{array}{c}\text { Rocha com } \\
\text { presença de } \\
\text { fraturas } \\
\text { localizadas e com } \\
\text { aparência de risco } \\
\text { moderado de } \\
\text { queda de blocos } \\
\end{array}$ & $\begin{array}{c}\text { Rocha } \\
\text { moderadamente } \\
\text { fraturada com } \\
\text { grande risco de } \\
\text { queda de } \\
\text { lascas/blocos }\end{array}$ & $\begin{array}{c}\text { Rocha } \\
\text { extremamente } \\
\text { fraturada com } \\
\text { alto risco de } \\
\text { queda de } \\
\text { lascas/blocos }\end{array}$ \\
\hline $\begin{array}{l}\text { Qualidade } \\
\text { estrutural das } \\
\text { moradias }\end{array}$ & $\begin{array}{c}\text { Casas revestidas } \\
\text { com bom aspecto } \\
\text { e utilização de } \\
\text { materiais de } \\
\text { construção de boa } \\
\text { qualidade, } \\
\text { fundação em } \\
\text { material estável, } \\
\text { longe da crista e } \\
\text { base de taludes. }\end{array}$ & $\begin{array}{l}\text { Casas de alvenaria } \\
\text { com ou sem } \\
\text { revestimento, com } \\
\text { fundação em } \\
\text { material estável e } \\
\text { estrutura } \\
\text { deficiente }\end{array}$ & $\begin{array}{l}\text { Casas de alvenaria } \\
\text { com fundação e } \\
\text { estrutura } \\
\text { deficiente, sem } \\
\text { calha, localizadas } \\
\text { próximas a crista } \\
\text { e/ou base de } \\
\text { talude. }\end{array}$ & $\begin{array}{l}\text { Casas de alvenaria } \\
\text { sem fundação, sem } \\
\text { calha, estrutura } \\
\text { deficiente, com } \\
\text { presença de } \\
\text { rachaduras. }\end{array}$ & $\begin{array}{c}\text { Casas de } \\
\text { alvenaria sem } \\
\text { fundação e sem } \\
\text { estrutura ou de } \\
\text { madeira, com } \\
\text { rachaduras e } \\
\text { presença de } \\
\text { afundamento do } \\
\text { solo em alguns } \\
\text { locais próximos } \\
\text { à casa }\end{array}$ \\
\hline $\begin{array}{l}\text { Impermeabilização } \\
\text { da encosta (\% de } \\
\text { ocupação de casas } \\
\text { e vias públicas) }\end{array}$ & 0 a $10 \%$ & 11 a $25 \%$ & 26 a $35 \%$ & 36 a $45 \%$ & Acima $45 \%$ \\
\hline $\begin{array}{c}\text { Existência de } \\
\text { acesso de pedestres } \\
\text { e viários sem } \\
\text { pavimentação (\% } \\
\text { de ruas não } \\
\text { calçadas) } \\
\end{array}$ & 0 a $10 \%$ & 11 a $25 \%$ & 26 a $40 \%$ & 41 a $50 \%$ & Acima 50\% \\
\hline $\begin{array}{l}\text { Aspectos } \\
\text { geotécnicos }\end{array}$ & $\begin{array}{l}\text { Solo residual sem } \\
\text { indícios de } \\
\text { processo erosivo } \\
\text { ou cicatrizes de } \\
\text { deslizamentos }\end{array}$ & $\begin{array}{l}\text { Colúvio sem sinais } \\
\text { de rastejo e/ou } \\
\text { solo residual com } \\
\text { início de processo } \\
\text { erosivo sem } \\
\text { cicatrizes de } \\
\text { deslizamentos }\end{array}$ & $\begin{array}{l}\text { Colúvio com } \\
\text { pequenos sinais de } \\
\text { rastejo ou solo } \\
\text { residual com } \\
\text { sulcos e/ou } \\
\text { algumas cicatrizes } \\
\text { de deslizamentos }\end{array}$ & $\begin{array}{c}\text { Colúvio com } \\
\text { sinais de rastejo ou } \\
\text { solo residual com } \\
\text { ravinas e/ou } \\
\text { quantidade média } \\
\text { de cicatrizes de } \\
\text { deslizamentos; } \\
\text { presença de } \\
\text { trincas no solo } \\
\end{array}$ & $\begin{array}{l}\text { Colúvio com } \\
\text { sinais de rastejo } \\
\text { com muitas } \\
\text { trincas; contato } \\
\text { abrupto solo- } \\
\text { rocha e solo } \\
\text { residual com } \\
\text { voçorocas }\end{array}$ \\
\hline $\begin{array}{l}\text { Densidade de } \\
\text { ocupação da } \\
\text { encosta }(\%)\end{array}$ & 0 a $15 \%$ & 16 a $30 \%$ & 31 a $50 \%$ & 51 a $65 \%$ & Acima de $65 \%$ \\
\hline
\end{tabular}

Após a obtenção dos dados históricos da Coordenadoria de Defesa Civil, foi confeccionado um Mapa de Localização de Ocorrências de Deslizamentos de Terra e de Enchentes, com base nas ocorrências georreferenciadas entre 2003 e 2009 e que foram superpostos aos mapas hipsométrico, de declividade e orientação das encostas. 


\section{RESULTADOS E DISCUSSÃO}

Os resultados aqui apresentados são um resumo do que tem sido feito, como parte do convênio com o LNCC, e foram separados em três subitens: o primeiro relativo a algumas vistorias feitas ao longo do referido projeto; o segundo, referente à análise da série histórica da ocorrência dos eventos de deslizamentos (2003 e 2009) de acordo com os índices pluviométricos e o terceiro, que diz respeito à análise dos mapas hipsométrico, orientação das encostas e declividade, relacionados com a ocorrência de enchentes e deslizamentos no Bairro do Quitandinha.

\subsection{Resultados de algumas vistorias feitas no bairro do Quitandinha.}

Neste subitem apresentamos a classificação de duas áreas de risco da área piloto o bairro Quitandinha, atribuindo níveis de risco às variáveis contidas na Tabela de Fatores de Vulnerabilidade para Deslizamentos de Terra (Tabelas 3, 4 e 5).

Para atingir os objetivos dessa fase do projeto, foi realizada uma vistoria de campo, no dia 27/04/2009, a algumas localidades do bairro Quitandinha, que, segundo técnicos da Defesa Civil de Petrópolis, constituem-se em áreas com problemas relativos à instabilidade dos materiais das encostas.

As áreas selecionadas para a realização dessa etapa do projeto correspondem às seguintes localidades:

\begin{tabular}{|ccc|}
\hline Áreas & Endereço & $\begin{array}{c}\text { Coordenadas } \\
\text { UTM }\end{array}$ \\
\hline $\mathbf{1}$ & Rua Minas Gerais - parte I, Quitandinha, Petrópolis, RJ & $0683454 ; 7508105$ \\
\hline $\mathbf{2}$ & Rua Minas Gerais - parte II , Quitandinha, Petrópolis, RJ & $0683726 ; 7508222$ \\
\hline $\mathbf{3}$ & Rua Minas Gerais - parte III , Quitandinha, Petrópolis, RJ & $0683785 ; 7508404$ \\
\hline
\end{tabular}




\section{a) Área 1}

A Rua Minas Gerais localiza-se em área de encosta, com altitude inicial de $951 \mathrm{~m}$, caracterizando-se como ocupação típica de área de risco de deslizamento de terra, pois a declividade média das encostas dessa rua varia entre $45^{\circ}$ e $70^{\circ}$, em medidas tomadas com a Bússola de Geólogo Brunton. Apenas pela declividade em que se encontram as moradias, a área já deveria ser desocupada, pois se caracteriza como APP - Área de Proteção Permanente.

A rua possui problemas na sua rede de infra-estrutura, como ausência de captação de água da chuva, de rede de esgoto, calçamento de paralelepípedos com sinais de desgaste, deficiências na rede coletora de lixo, etc. A figura 2 mostra a Rua Minas Gerais no seu inicio.

Segundo relato dos moradores, essa rua sofre constantemente com deslizamentos de terra. Há algumas casas embargadas pela Defesa Civil, pois se encontram muito próximas de uma encosta que deslizou recentemente. As figuras 3, 4 e 5 ilustram uma casa que foi atingida por deslizamento de terra, causado por elevada quantidade de chuva e contato solo-rocha abrupto. Nesse episódio morreram duas pessoas. 


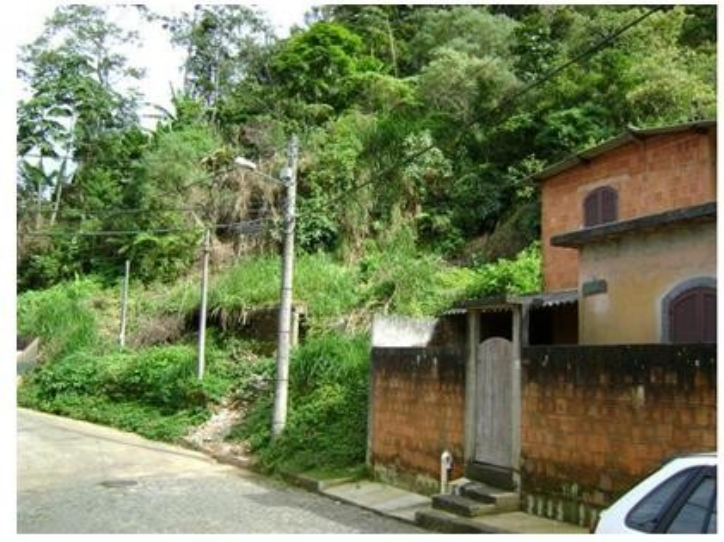

Figura 2: Inicio da Rua Minas Gerais. Foto F. S. Lima.

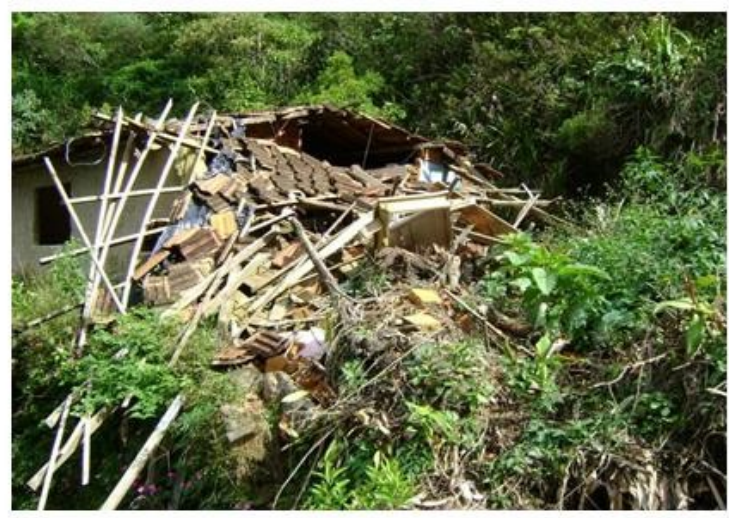

Figura 4: Destroços da casa que foi atingida por deslizamento de terra. Foto F.S. Lima.
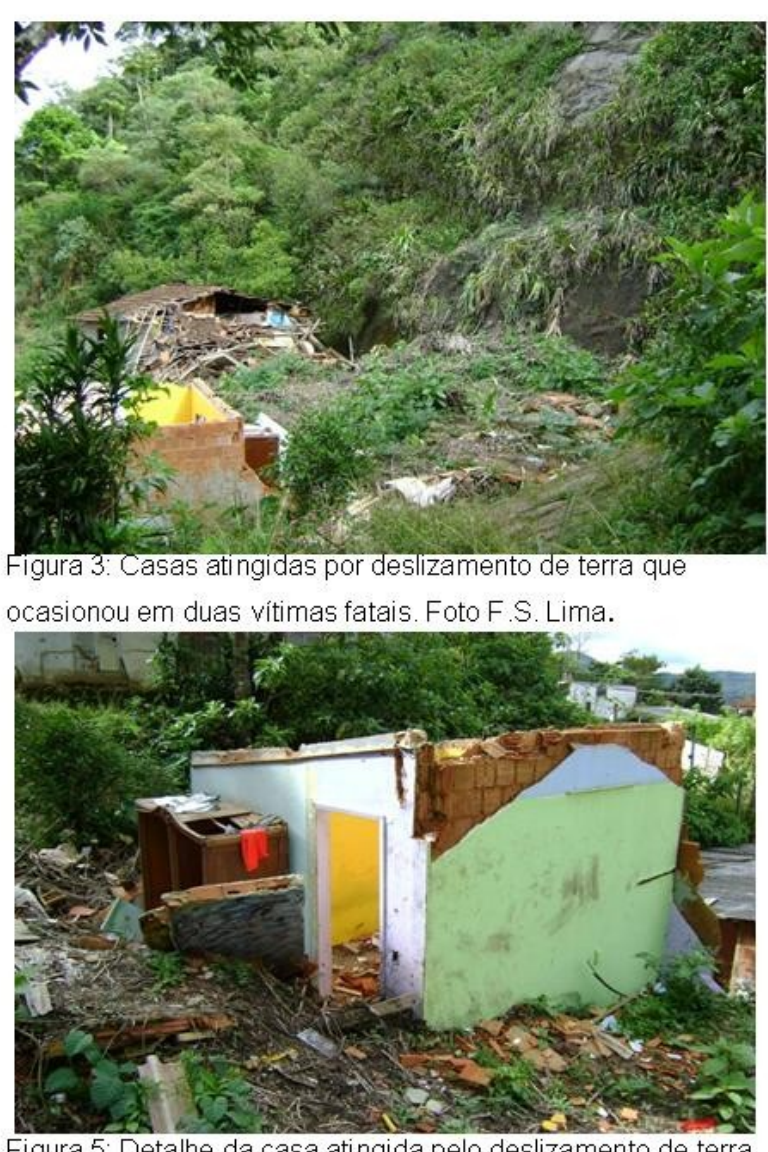

Figura 5: Detalhe da casa atingida pelo deslizamento de terra Casa construída sob depósito de tálus. Foto F.S. Lima.

Atrás da Rua Minas Gerais há um afloramento rochoso bastante fraturado, e segundo relato de moradores, a camada de solo que recobre o maciço se encontra fofa e úmida, devido ao lançamento de água servida da comunidade que reside na parte de cima da rua (Rua Minas Gerais - parte 2). As figuras 6 e 7 mostram a cicatriz do deslizamento e a proximidade das casas com a encosta atingida.

Há uma nascente no afloramento rochoso, que abastece de água toda a Rua Minas Gerais, deixando o solo úmido por onde os canos de abastecimento ilegal passam. Esses canos estão presentes por toda a rua, às vezes enterrados na encosta ou expostos (Figuras 8 e 9). 


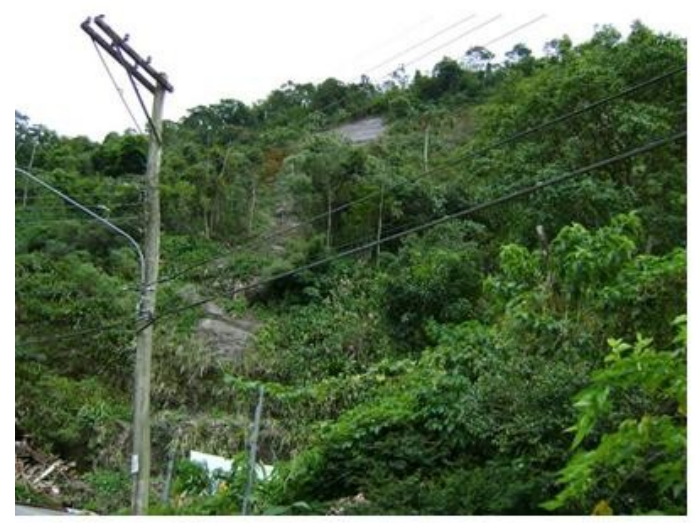

Figura 6. Cicatriz de deslizamento. Foto F. S. Lima.

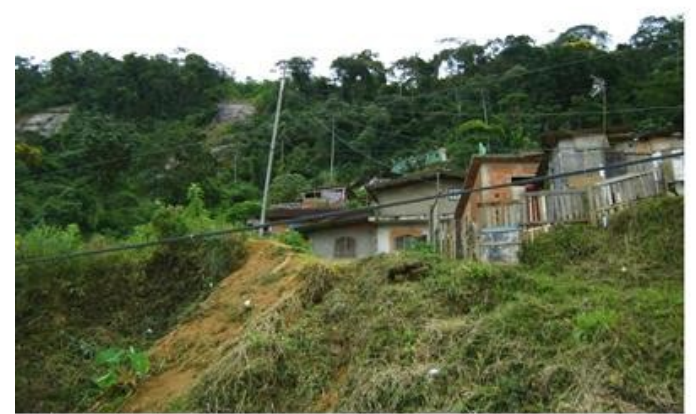

Figura 8. Canos de abastecimento de água ilegal, presentes por toda a comunidade. Foto F. S. Lima.

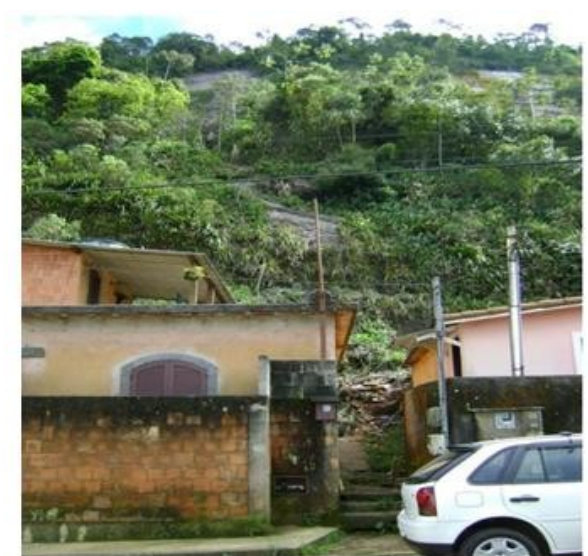

Figura 7. Casas muito próxima do afloramento rochoso. Declividade da encosta: $67^{\circ}$. Perigo de novos deslizamentos. Foto F. S. Lima.

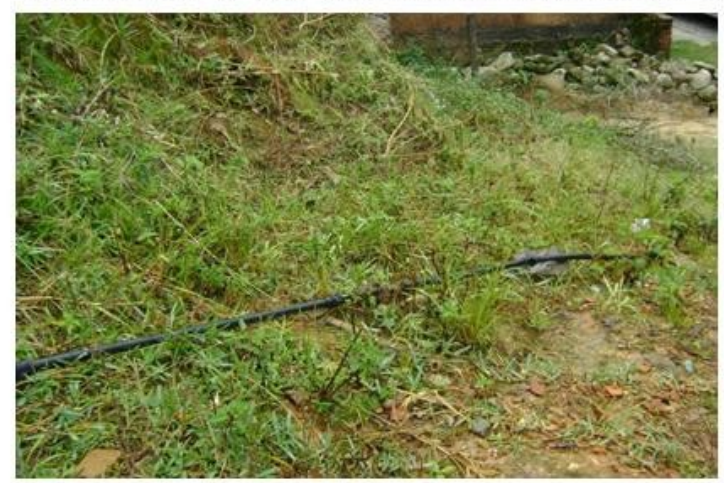

Figura 9. Detalhe de cano de abastecimento ilegal de água. Notar os remendos com fita isolante nos canos, e o constante vazamento de água Foto F S I ima

Apesar de a área ser palco de inúmeros deslizamentos de terra no passado, o poder público ignora essa área completamente. Não há rede coletora de esgoto, assim como também não há rede coletora de águas pluviais (Figura 10). Em dias de chuva, o aporte de água é muito grande, o que preocupa toda a comunidade. 


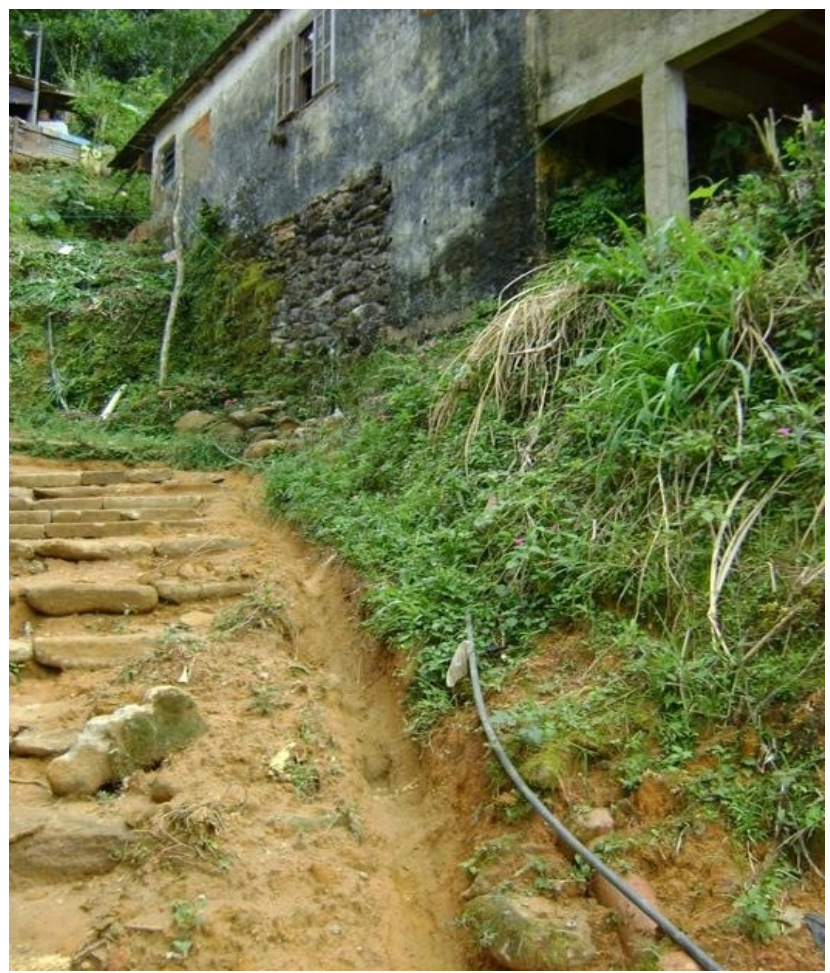

Figura 10. Pequena canaleta feita pelos moradores para escoar a água que desce a encosta em dias de pluviosidade intensa. F. S. Lima.

Os moradores constroem suas casas de forma precária, através do corte de talude e aterro, formando degraus escalonados de casas. Esse perfil de ocupação é muito perigoso, principalmente se levarmos em consideração o histórico da área, as características físicas da região e as atividades antrópicas negativas, como o lançamento de esgoto direto na encosta. As figuras 11, 12 e 13 mostram o perfil das construções e o tipo de corte presente nos fundos de quase todas as moradias. 


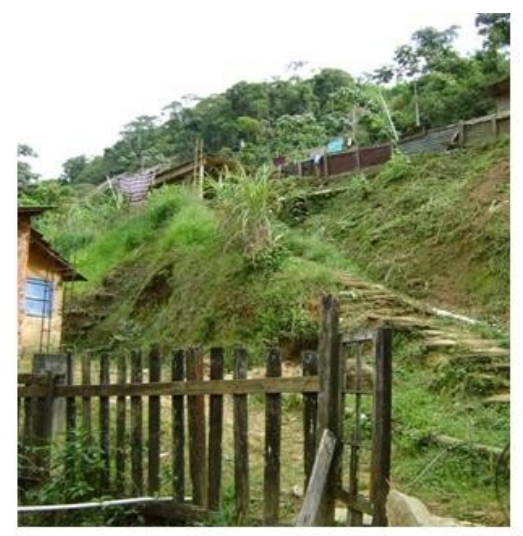

Figura 11: Escadaria rudimentar feita pelos próprios moradores e casas de madeira na Parte alta da ocupação. Foto: Fabio S. Lima

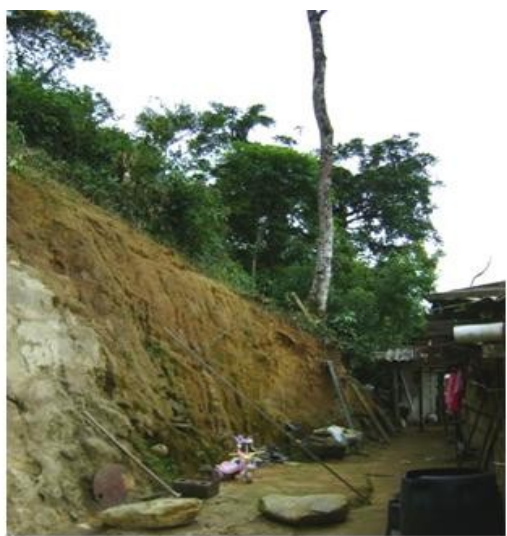

Figura 12: Corte de talude nos fundos de uma casa. F. S. Lima.

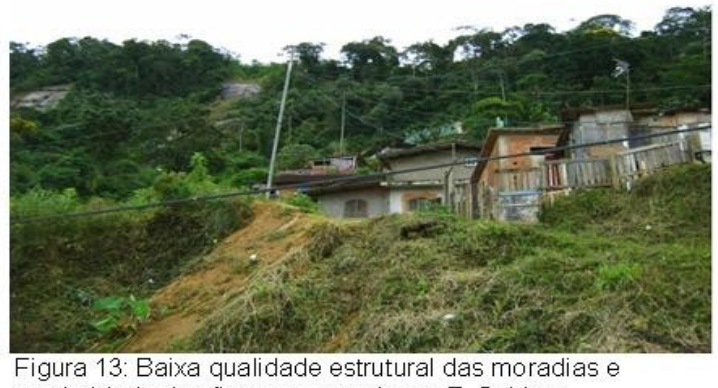

Figura 13: Baixa qualidade estrutural das moradias
proximidade do afloramento rochoso. F. S. Lima.

Após a análise das variáveis geológico-geomorfológicas e sociais encontradas na área, pode-se estabelecer que e a Rua Minas Gerais - parte 1 possui um grau de risco alto a deslizamentos de terra nessa região, como indica a Tabela 3: 
Tabela 3 - Fatores de Vulnerabilidade da Área 18, níveis de risco e classificação.

\begin{tabular}{|c|c|}
\hline $\begin{array}{l}\text { FATORES DE VULNERABILIDADE PARA DESLIZAMENTOS } \\
\text { DE TERRA }\end{array}$ & NÍVEL DO FATOR \\
\hline Declividade & N5 \\
\hline Drenagem natural & N4 \\
\hline Rede de esgoto sanitário & $\mathrm{N} 2$ \\
\hline Rede de águas pluviais & N5 \\
\hline Abastecimento de água & N3 \\
\hline Lançamento de detritos (lixo/entulho) & N5 \\
\hline Existência de cortes e/ou aterros & N5 \\
\hline Existência de obras de estabilização & N5 \\
\hline Cobertura vegetal & N3 \\
\hline Existência de matacões superficiais & N4 \\
\hline Aspectos lito-estruturais & N4 \\
\hline Qualidade estrutural das moradias & N4 \\
\hline Impermeabilização da encosta & N3 \\
\hline Acesso de pedestres e viários sem pavimentação & N3 \\
\hline Aspectos geotécnicos & N5 \\
\hline Densidade de ocupação da encosta & N3 \\
\hline Média aritmética dos fatores & 3,9 \\
\hline CLASSE DE RISCO & ALTO \\
\hline
\end{tabular}

\section{b) Área 2}

A Rua Minas Gerais parte 2 caracteriza-se pelo fim da Rua Minas Gerais, onde a qualidade estrutural das moradias melhora bastante, assim como a eficiência dos serviços públicos, como calçamento, coleta de lixo e abastecimento de água e rede de esgoto.

A encosta na parte de trás da rua não possui afloramento rochoso aparente, nem matacões expostos, e possui boa parte da sua cobertura vegetal preservada, fazendo com que a área não seja considerada como de risco atual de ocupação. A densidade de ocupação nessa área é baixa, tornando bem menor o risco de vítimas fatais devido a deslizamentos de terra. As figuras 14 e 15 mostram o perfil de ocupação da encosta e a cobertura vegetal da área. 


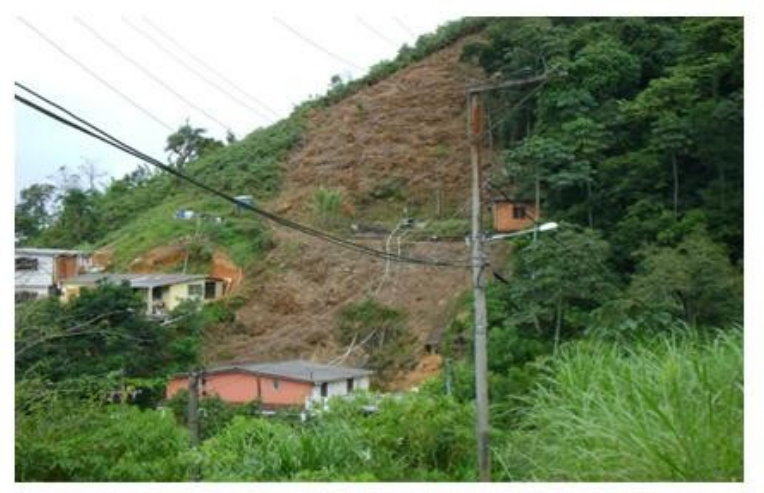

Figura 14: Baixa densidade de ocupação na Rua Minas Gerais. Ocupaçôes típicas em áreas de baixa a média encosta. Foto F. S. Lima.

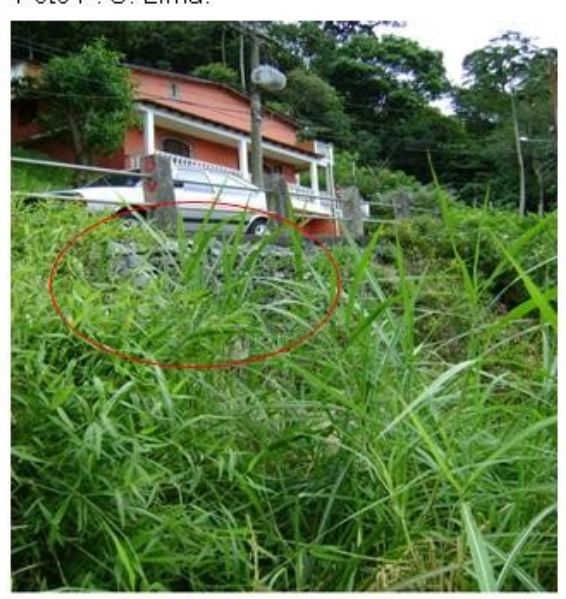

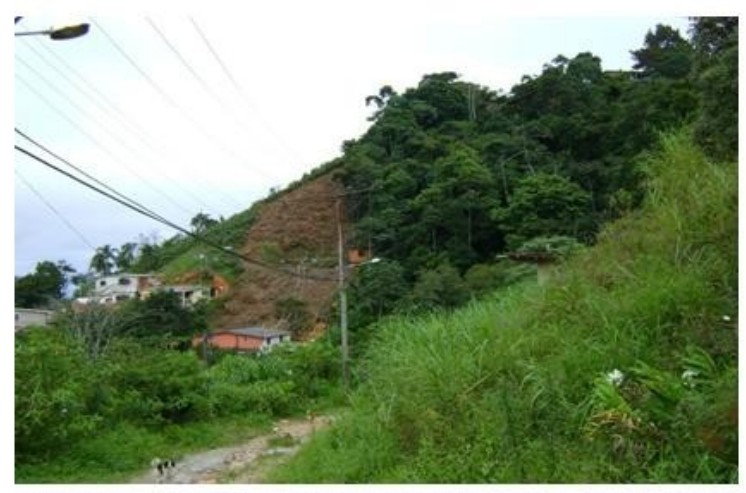

Figura 15: Parte da cobertura vegetal dessa área está preservada, com florestas de médio a grande porte, principalmente na parte Alta da encosta. Foto: F.S. Lima

No fim da rua, numa área de convergência de fluxos, parte da encosta abaixo do nível da rua deslizou em 1988, sendo necessária a construção de um muro de contenção por parte da prefeitura. A declividade nesse ponto é de $56^{\circ}$, o que é considerada muito alta, porém os moradores afirmam que a declividade era muito maior. Devido à dificuldade de acesso causada pela elevada declividade, a figura 16 mostra apenas parte desse muro de contenção.

Nessa área passa um enorme cano da Companhia Águas do Imperador, sendo motivo de preocupação para os moradores que aí residem, visto que houve um episódio de estouro de tubulação em que a terra da encosta deslizou, atingindo as casas situadas mais a jusante.Porém os moradores estão atentos a qualquer atividade que prejudique a estabilidade da encosta. Um exemplo disso foi a demolição de uma casa, por iniciativa dos próprios moradores, por considerarem que a casa estava causando um sobrepeso na 
encosta. No local hoje há apenas capim, mas já foram plantadas mudas de árvores de diversos tipos. Assim, de acordo com as variáveis geológico-geomorfológicas e sociais encontradas na área, pode-se estabelecer que e a Rua Minas Gerais - parte 2 possui um grau de risco alto a deslizamentos de terra nessa região, como indica a Tabela 4:

Tabela 4 - Fatores de Vulnerabilidade da Área 2, níveis de risco e classificação.

\begin{tabular}{|c|c|}
\hline $\begin{array}{c}\text { FATORES DE VULNERABILIDADE PARA DESLIZAMENTOS DE } \\
\text { TERRA }\end{array}$ & NíVEL DO FATOR \\
\hline Declividade & N5 \\
\hline Drenagem natural & N3 \\
\hline Rede de esgoto sanitário & N3 \\
\hline Rede de águas pluviais & N3 \\
\hline Abastecimento de água & N3 \\
\hline Lançamento de detritos (lixo/entulho) & N4 \\
\hline Existência de cortes e/ou aterros & N3 \\
\hline Existência de obras de estabilização & N3 \\
\hline Cobertura vegetal & N3 \\
\hline Existência de matacões superficiais & N4 \\
\hline Aspectos lito-estruturais & N3 \\
\hline Qualidade estrutural das moradias & N2 \\
\hline Impermeabilização da encosta & N3 \\
\hline Acesso de pedestres e viários sem pavimentação & N3 \\
\hline Aspectos geotécnicos & N3 \\
\hline Densidade de ocupação da encosta & N2 \\
\hline Média aritmética dos fatores & $\mathbf{3 , 1}$ \\
\hline CLASSE DE RISCO & NTO \\
\hline
\end{tabular}

\section{c) Area 3}

A parte alta da Rua Minas Gerais caracteriza-se por uma ocupação ilegal, quase toda em área de topo de morro, cuja altitude inicial é de $1001 \mathrm{~m}$. Segundo moradores, foram depositados mais de 40 caminhões de aterro para aumentar a área, o que pode ser 
visto no dia da visita de campo, quando dois caminhões de entulho subiram em direção ao final da rua.

A infra-estrutura nesse local é ainda mais precária que na parte de baixo da rua, não havendo asfalto, calçamento, coleta de lixo, abastecimento de água oficial, rede de esgoto, ou linhas de ônibus. A figura 17 mostra o início do acesso à parte alta da Rua Minas Gerais.

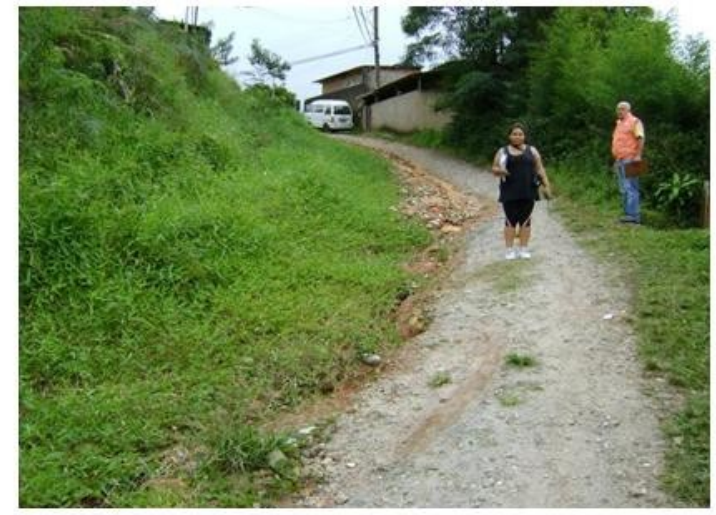

Figura 17: Acesso ao início da Rua Minas Gerais - parte 3. Observe o estado da via por onde passam pedestres e alguns Veículos. Presença de ravinamento. Foto: F.S.Lima

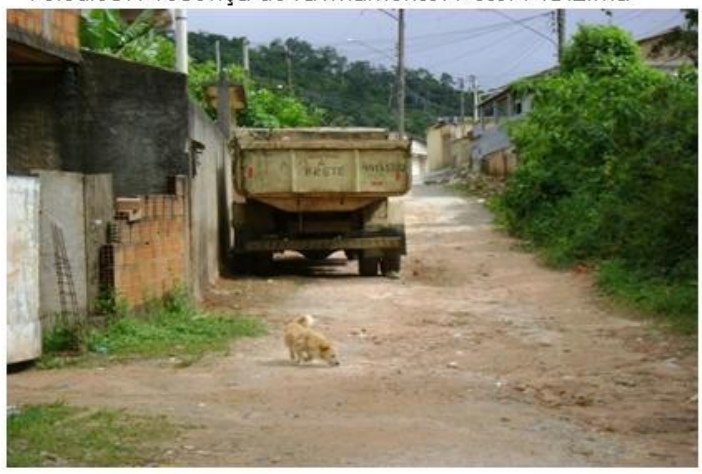

Figura 19: Rua Minas Gerais na parte de cima. Notar a ausência total de infra-estrutura e os processos erosivos na rua. Foto F. S. Lima

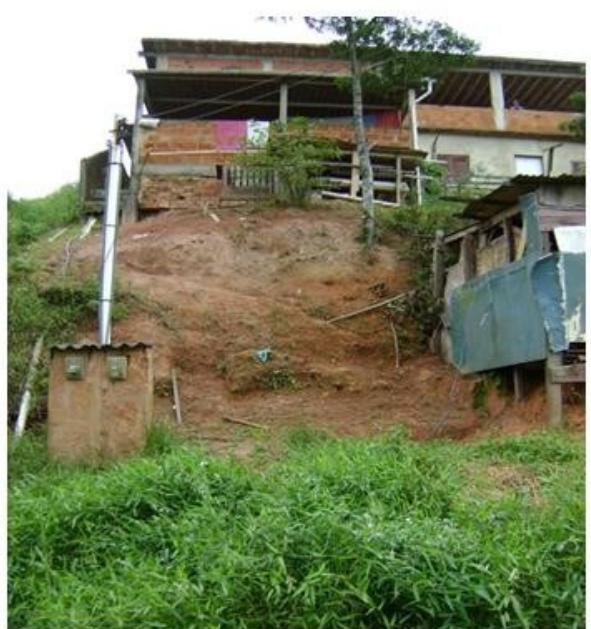

Figura 18: Aspecto estrutural de casa na parte de cima da Rua Minas Gerais. Foto F. S. Lima.

A rua está sendo erodida, pois são freqüentes os sinais de rastejo e ravinamento, tanto no acesso à parte de cima da rua, quanto nas encostas e de ocupação recente (Figuras 18 e 19).

Há abundante presença de lixo ao longo do caminho e na encosta. Devido à falta de coleta, a comunidade despeja lixo nas encostas e em terrenos ainda não ocupados, causando transtornos nas épocas de chuva. Esse lixo não coletado se acumula abaixo da 
cobertura vegetal e nas áreas preferenciais de escoamento de água, como as canaletas. As figuras 20, 21 e 22 ilustram esse problema.

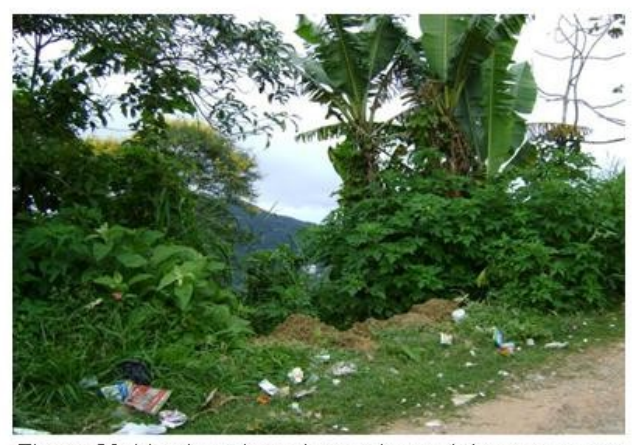

Figura 20: Lixo jogado ao longo do caminho e pequeno A.terro na encosta. Foto: F.S. LIma

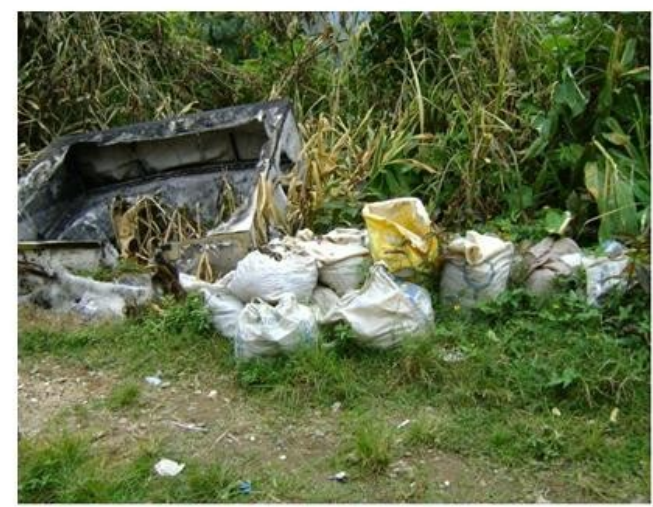

Figura 22: Lixo jogado ao longo do caminho. Foto F.S Lima

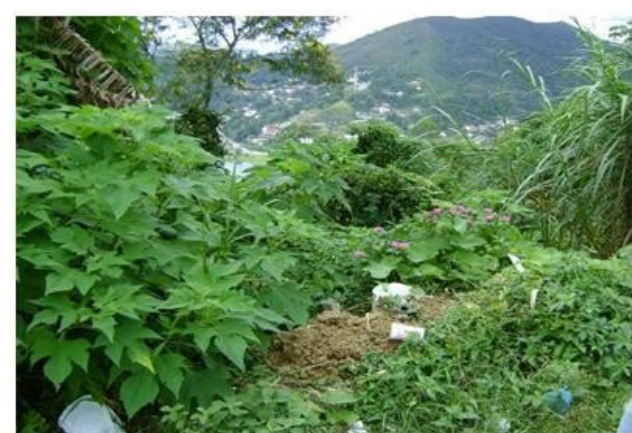

Figura 21: Detalhe da foto anterior, mostrando o resto de Obra e lixo. Foto: F.S.Lima

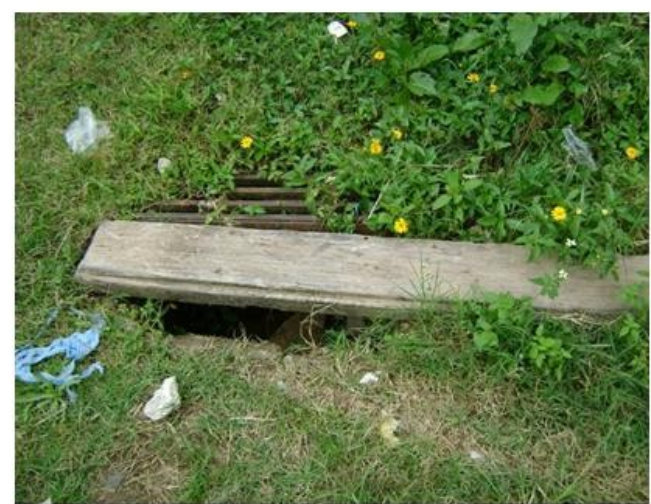

Figura 23: Canaleta parcialmente entupida e que não dá vazăo ao grande volume de água durante as chuvas intensas. Foto F. S. Lima.

As poucas canaletas que existem estão parcialmente entupidas e não dão vazão ao grande volume de água nas épocas das chuvas (Figura 23).

Na parte alta da Rua Minas Gerais algumas casas foram construídas em área de convergência de fluxos, ou seja, de grande risco de deslizamento de terra, visto que o aporte de água nessa área, em épocas de chuva, é muito grande. A figura 24 mostra essa situação. 


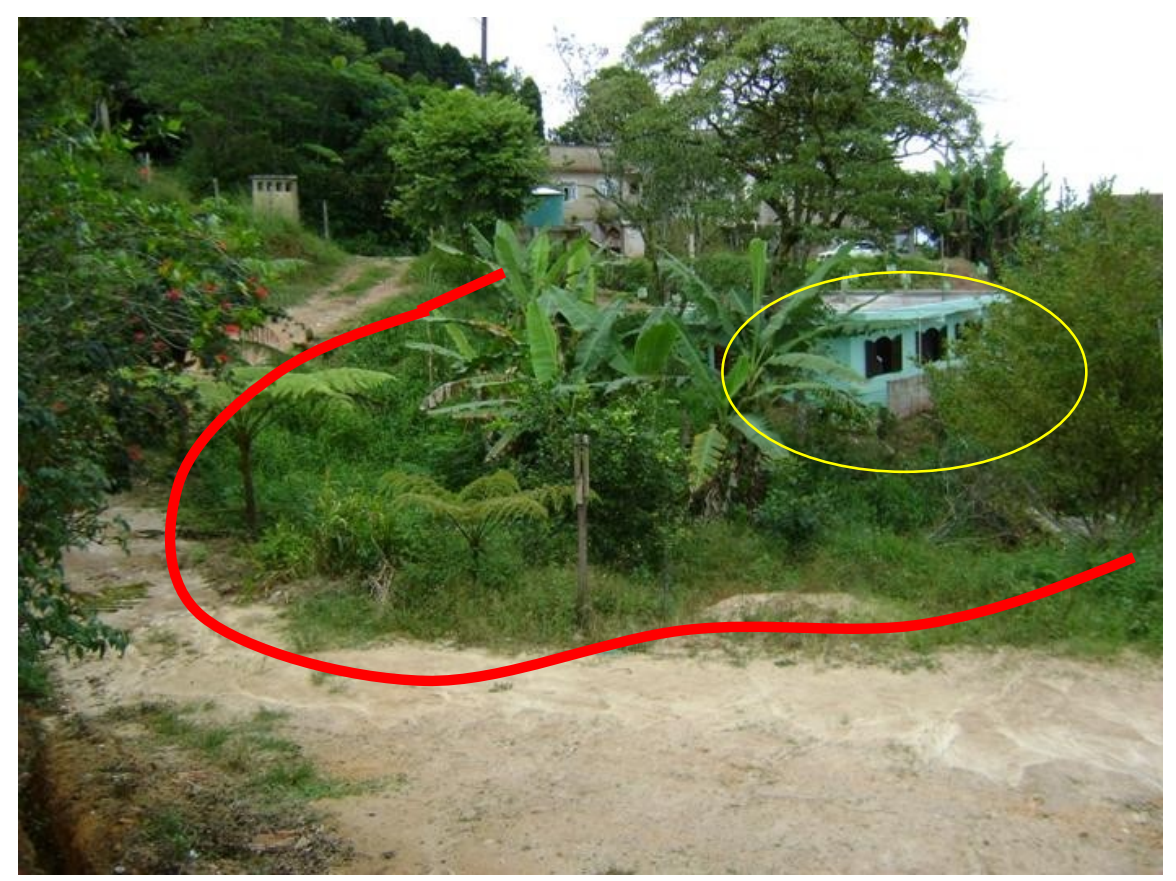

Figura 24: Grande área de convergência de fluxos, com presença de casas dentro dessa área côncava (anfiteatro). Foto F. S. Lima.

As demais residências encontram-se em área de topo de morro, onde foram construídos enormes platôs com aterro, que constituem hoje uma das principais variáveis que contribuem para a maior probabilidade de deslizamentos de terra nessa região. A figura 25 mostra a diferença de altura do nível do terreno antigo e do que foi aterrado. Essa diferença de altura é a média do que foi aterrado nessa região.

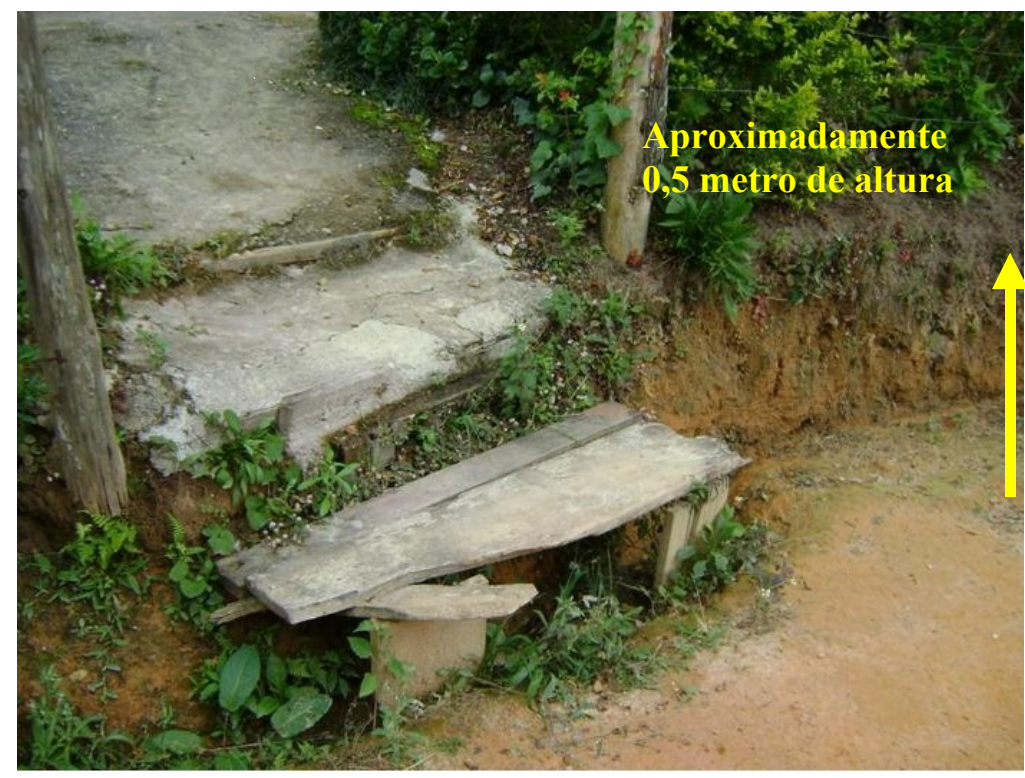

Figura 25: Diferença de altura de terreno que foi aterrado há quatro anos. Foto F. S. ima. 
Há outros locais onde essa altura de aterro ultrapassa um metro, como mostra a figura 26, onde essa diferença cada vez se aprofunda mais, devido aos agentes erosivos.

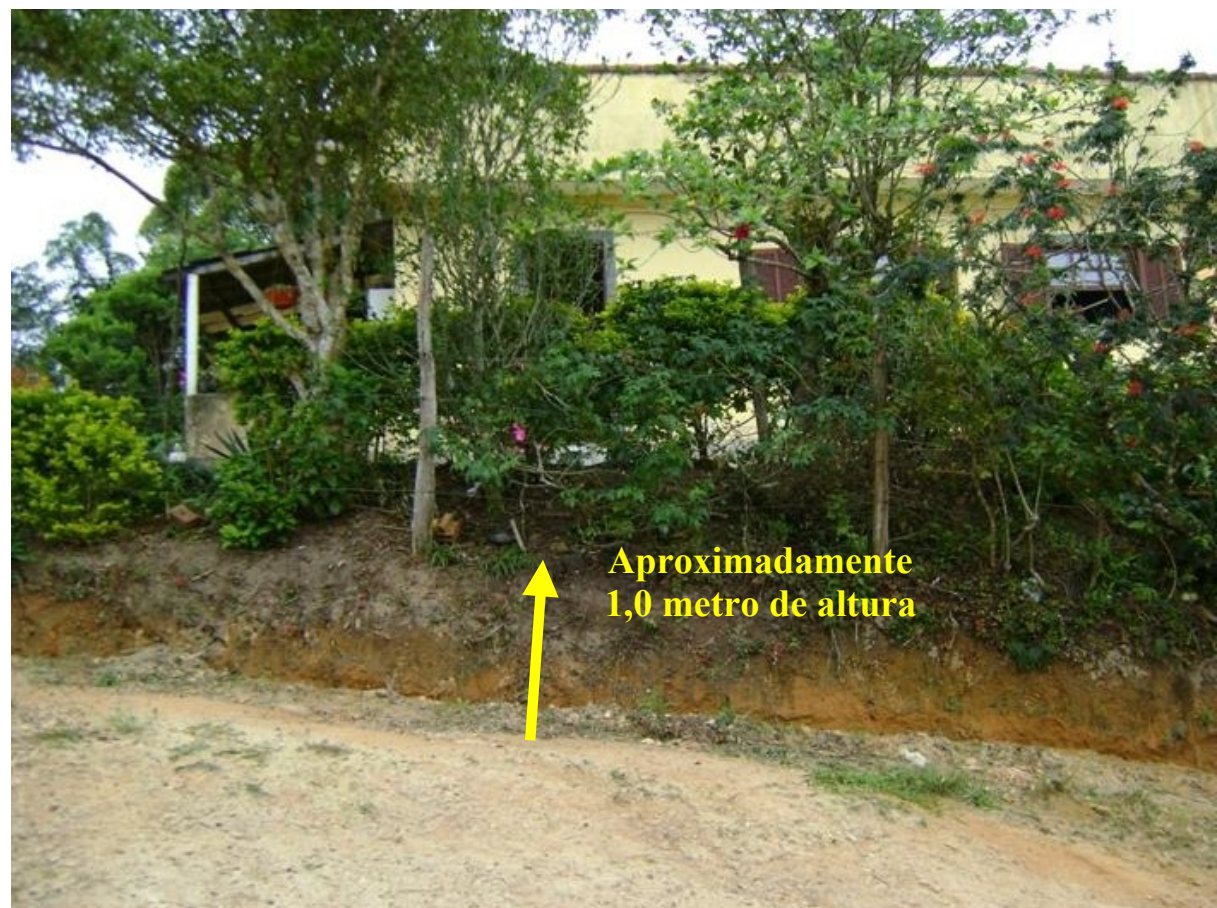

Figura 26: Aterro colocado pela população no início da ocupação dessa localidade. Atualmente essa diferença de altura vem aumentando devido à erosão do sopé desse pequeno corte. Foto F. S. Lima.

Nessa área as casas apresentam deficiências na estrutura, aparentando pouca qualidade das moradias, o que a torna, já tão instável do ponto de vista geomorfológico, ainda mais propensa a deslizamentos de terra. Essas residências não possuem calha, o que se caracteriza como mais um agravante nesse contexto de risco a deslizamentos de terra. A figura 27 mostra o perfil das casas dessa área. 


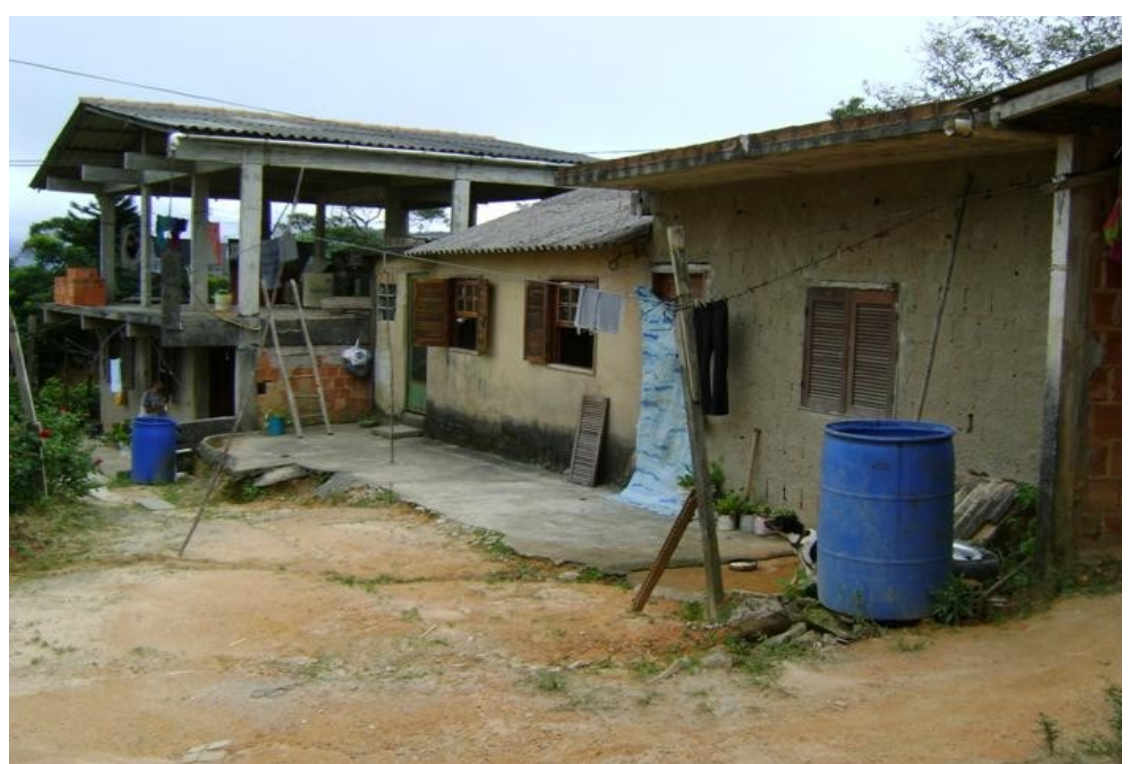

Figura 27: Casas construídas no topo da encosta aterrada. Casas sem calha e com processo de ravinamento do terreno. Foto F. S. Lima.

Para piorar a situação, a declividade da borda da encosta é muito elevada $\left(65^{\circ}\right)$, e as casas foram construídas no limite da mesma. A figura 28 ilustra uma casa nessa situação.

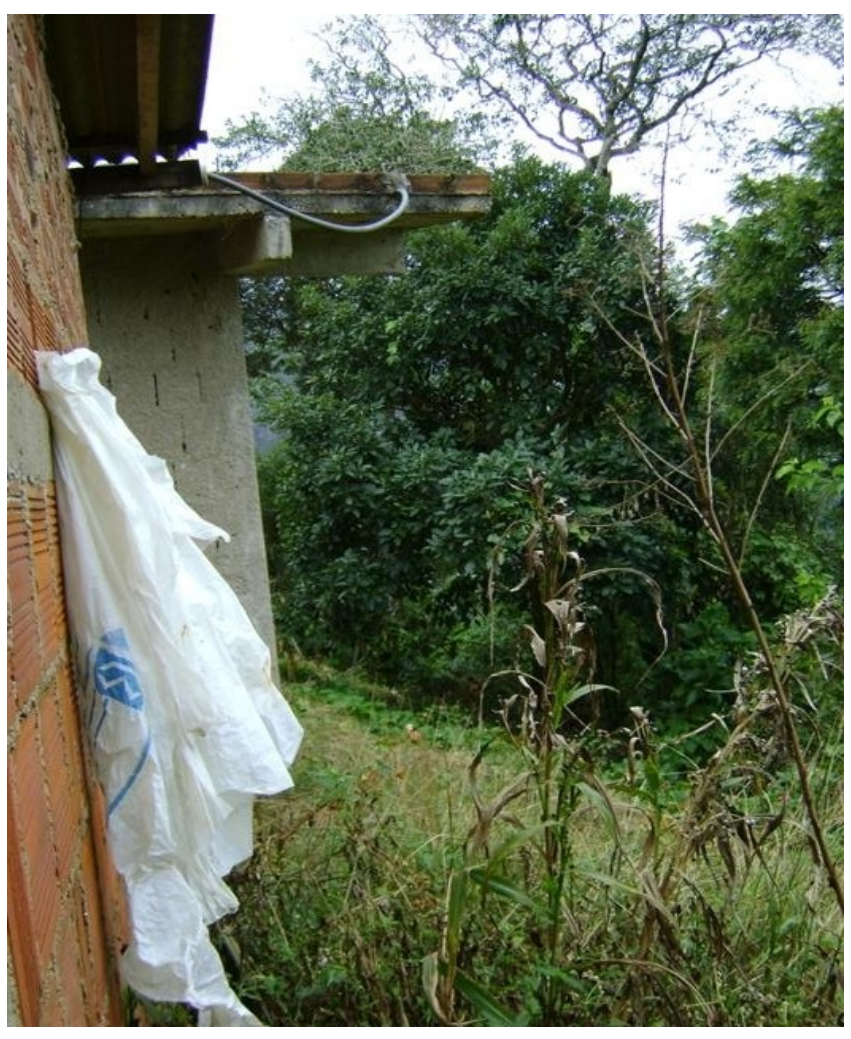

Figura 28: Casas construídas no limite do topo da encosta aterrada. Foto F. S. Lima. 
Segundo relato dos moradores, as residências retiram a água direto da nascente e despejam seus esgotos diretamente na encosta. Não foi possível fotografar essa situação porque os canos encontram-se enterrados na encosta (o que torna a identificação de vazamentos bem mais difícil). Assim, de acordo com as variáveis geológicogeomorfológicas e sociais encontradas na área analisada, estabelecemos o grau de risco alto a deslizamentos de terra nessa região, como indica a Tabela 5:

Tabela 5. Fatores de Vulnerabilidade da Área 20, níveis de risco e classificação.

\begin{tabular}{|c|c|}
\hline $\begin{array}{l}\text { FATORES DE VULNERABILIDADE PARA DESLIZAMENTOS DE } \\
\text { TERRA }\end{array}$ & NÍVEL DO FATOR \\
\hline Declividade & N5 \\
\hline Drenagem natural & N3 \\
\hline Rede de esgoto sanitário & $\mathrm{N} 2$ \\
\hline Rede de águas pluviais & $\mathrm{N} 3$ \\
\hline Abastecimento de água & N3 \\
\hline Lançamento de detritos (lixo/entulho) & N4 \\
\hline Existência de cortes e/ou aterros & N4 \\
\hline Existência de obras de estabilização & N4 \\
\hline Cobertura vegetal & N3 \\
\hline Existência de matacões superficiais & $\mathrm{N} 2$ \\
\hline Aspectos lito-estruturais & NA \\
\hline Qualidade estrutural das moradias & N3 \\
\hline Impermeabilização da encosta & N4 \\
\hline Acesso de pedestres e viários sem pavimentação & N4 \\
\hline Aspectos geotécnicos & N4 \\
\hline Densidade de ocupação da encosta & N3 \\
\hline Média aritmética dos fatores & 3,4 \\
\hline CLASSE DE RISCO & ALTO \\
\hline
\end{tabular}

3.2. Análise da série histórica da ocorrência dos eventos de deslizamentos (2003 e 2009) de acordo com os índices pluviométricos. 
A partir dos dados de ocorrência de acidentes fornecidos pela Coordenadoria de Defesa Civil da Prefeitura Municipal de Petrópolis e dos dados de pluviometria fornecidos pelo LNCC para o período situado entre 2003 e 2009 foi possível elaborar uma série histórica de todos os eventos referentes a deslizamentos e enchentes da áreapiloto (Bairro do Quitandinha). Obteve-se um total de 511 eventos.

Cada evento foi relacionado com os índices pluviométricos ocorridos nos períodos de 24, 48 e $72 \mathrm{~h}$ que o antecederam. O objetivo desta correlação é definir valores de índices pluviométricos que, quando atingidos, exista uma alta probabilidade de ocorrência de deslizamentos de terra com acidentes. Estes índices poderão ser utilizados como um dos indicadores de uma situação de alerta por órgãos responsáveis pelo gerenciamento de risco, como a Coordenadoria de Defesa Civil.

Essa correlação entre ocorrência de deslizamentos com índices pluviométricos é feita posto que o principal agente deflagrador de um movimento de massa é a água no interior da massa de solo que, além de aumentar o peso do solo, eleva as poro-pressões dentro da massa de solo, que diminuem a sua resistência ao cisalhamento. Para a definição do período de pluviosidade a ser correlacionado com a ocorrência do evento, deve-se considerar que a percolação da água no subsolo varia de acordo com as características hidrogeológicas da região, sendo governada principalmente pela sua permeabilidade. Diante disso, um deslizamento não só depende dos índices pluviométricos referentes às poucas horas que o antecedeu, mas também dos dias anteriores.

O período mínimo considerado foi o de $24 \mathrm{~h}$, diante da falta de informação sobre o horário de ocorrência do evento. Portanto, foram escolhidos os índices pluviométricos de 24, 48 e 72h. A definição dos índices pluviométricos 24,48 e $72 \mathrm{~h}$ foi feita considerando que o evento tenha ocorrido às $24 \mathrm{~h}$ da data registrada pela Defesa Civil.

Os períodos de pluviosidade mais adequados para a correlação com enchentes deveriam ser menores que $24 \mathrm{~h}$, posto que esses eventos, no caso de Petrópolis, podem ocorrer nas primeiras horas de chuva. Entretanto não existem dados sobre o horário de ocorrência das enchentes, com os quais fosse possível fazer a correlação com os índices 
pluviométricos. Desta forma, foram adotados os mesmos períodos considerados para deslizamentos.

Para as análises com finalidade de se definir os índices críticos, não foram considerados os eventos que ocorreram com índices pluviométricos com totais de até 10 mm para as 24 horas, diante da falta de confiabilidade desses valores, sabendo que é um valor muito pequeno para provocar eventos catastróficos. Da mesma forma, foram desconsiderados os valores menores ou iguais a $20 \mathrm{~mm}$ para 48 horas e $40 \mathrm{~mm}$ para 72 horas.

Inicialmente apresentamos a variação da quantidade de eventos com os índices pluviométricos acumulados separados por classes. Nas tabelas 6 a 8 estão apresentadas as quantidades de eventos separadas por classes de índices pluviométricos para 24 horas, 48 horas e 72 horas que antecederam a ocorrência, respectivamente. Para o período de $24 \mathrm{~h}$ consideraram-se as classes de $10.1 \mathrm{~mm}$ a $20.0 \mathrm{~mm} ; 20.1 \mathrm{~mm}$ a $40.0 \mathrm{~mm} ; 40.1 \mathrm{~mm}$ a $60.0 \mathrm{~mm} ; 60.1 \mathrm{~mm}$ a $80.0 \mathrm{~mm}$ e $\geq 80.1 \mathrm{~mm}$. Para o período de $48 \mathrm{~h}$ consideraram-se as classes de $20.1 \mathrm{~mm}$ a $40.0 \mathrm{~mm} ; 40.1 \mathrm{~mm}$ a $80.0 \mathrm{~mm} ; 80.1 \mathrm{~mm}$ - $120.0 \mathrm{~mm} ; 120.1 \mathrm{~mm}$ $160.0 \mathrm{~mm}$ e $\geq 160.1 \mathrm{~mm}$. Para o período de $72 \mathrm{~h}$ consideraram-se as classes de $40.1 \mathrm{~mm}$ a $80.0 \mathrm{~mm} ; 80.1 \mathrm{~mm}$ a $120.0 \mathrm{~mm} ; 120.1 \mathrm{~mm}-160.0 \mathrm{~mm} ; 160.1 \mathrm{~mm}-200.0 \mathrm{~mm}$ e $\geq 200.1$ mm. Nas figuras 29 a 31 são apresentadas a variação do percentual acumulado de eventos com as classes de pluviometria os mesmos períodos de 24 horas, 48 horas e 72 horas 
Tabela 6. Distribuição das classes de índices pluviométricos para um período de 24 horas $\mathrm{x}$ ocorrências.

\begin{tabular}{|c|c|c|c|}
\hline \multirow{2}{*}{$\begin{array}{c}\text { Classes } \\
(\text { Chuvas mm })\end{array}$} & \multicolumn{3}{|c|}{ Quantidade de ocorrências } \\
\cline { 2 - 4 } & Enchentes & Deslizamentos & $\begin{array}{c}\text { Enchentes }+ \\
\text { Deslizamentos }\end{array}$ \\
\hline $10.1-20.0$ & 3 & 42 & 45 \\
\hline $20.1-40.0$ & 3 & 44 & 47 \\
\hline $40.1-60.0$ & 1 & 15 & 16 \\
\hline $60.1-80.0$ & 2 & 41 & 43 \\
\hline$\geq 80.1$ & 6 & 73 & 79 \\
\hline Total & 15 & 215 & 230 \\
\hline
\end{tabular}

Tabela 7. Distribuição das classes de índices pluviométricos para um período de 48 horas x ocorrências.

\begin{tabular}{|c|c|c|c|}
\hline \multirow{2}{*}{$\begin{array}{c}\text { Classes } \\
(\text { Chuvas mm })\end{array}$} & \multicolumn{3}{|c|}{ Quantidade de ocorrências } \\
\cline { 2 - 4 } & Enchentes & Deslizamentos & $\begin{array}{c}\text { Enchentes }+ \\
\text { Deslizamentos }\end{array}$ \\
\hline $20.1 \mathrm{~mm}-40.0 \mathrm{~mm}$ & 2 & 51 & 53 \\
\hline $40.1 \mathrm{~mm}-80.0 \mathrm{~mm}$ & 6 & 70 & 76 \\
\hline $80.1 \mathrm{~mm}-120.0 \mathrm{~mm}$ & 4 & 34 & 38 \\
\hline $120.1 \mathrm{~mm}-160.0 \mathrm{~mm}$ & 1 & 16 & 17 \\
\hline$\geq 160.1 \mathrm{~mm}$ & 6 & 75 & 81 \\
\hline Total & 19 & 246 & 265 \\
\hline
\end{tabular}


Tabela 8. Distribuição das classes de índices pluviométricos para um período de 72 horas x ocorrências

\begin{tabular}{|c|c|c|c|}
\hline \multirow{2}{*}{ Classes (Chuvas mm) } & \multicolumn{3}{|c|}{ Quantidade de ocorrências } \\
\cline { 2 - 4 } & Enchentes & Deslizamentos & $\begin{array}{c}\text { Enchentes }+ \\
\text { Deslizamentos }\end{array}$ \\
\hline $40.1 \mathrm{~mm}-80.0 \mathrm{~mm}$ & 8 & 77 & 85 \\
\hline $80.1 \mathrm{~mm}-120.0 \mathrm{~mm}$ & 6 & 60 & 66 \\
\hline $120.0 \mathrm{~mm}-160.0 \mathrm{~mm}$ & 2 & 7 & 9 \\
\hline $160.1 \mathrm{~mm}-200.0 \mathrm{~mm}$ & 0 & 22 & 82 \\
\hline$\geq 200.1 \mathrm{~mm}$ & 6 & 76 & 264 \\
\hline Total & 22 & 242 & 92 \\
\hline
\end{tabular}

Chuva (24horas)

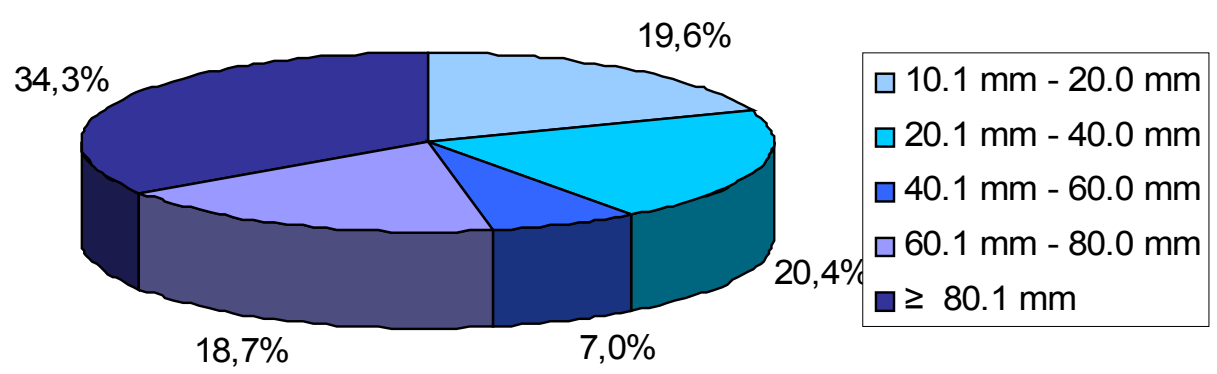

Figura 29. Freqüência acumulada dos eventos (enchentes + deslizamentos) de acordo com as de pluviometria para um período de $24 \mathrm{~h}$. 


\section{Chuva (48horas)}

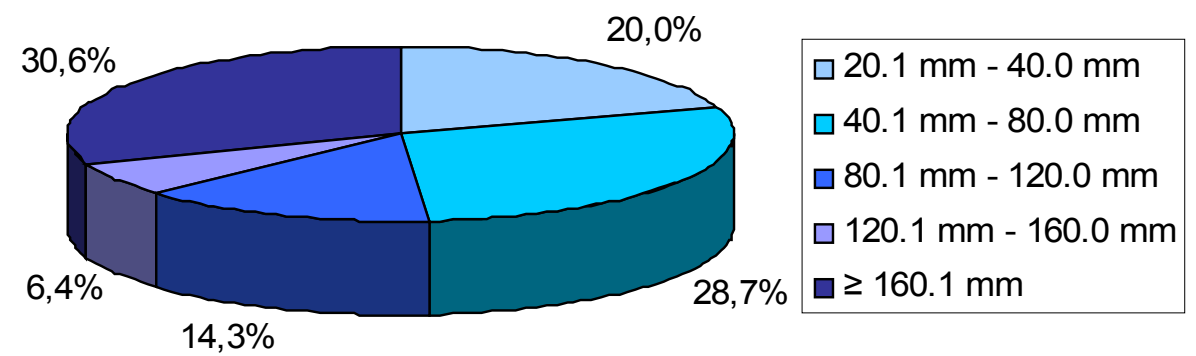

Figura 30. Freqüência acumulada dos eventos (enchentes + deslizamentos) de acordo com as de pluviometria para um período de $48 \mathrm{~h}$.

\section{Chuva (72horas)}

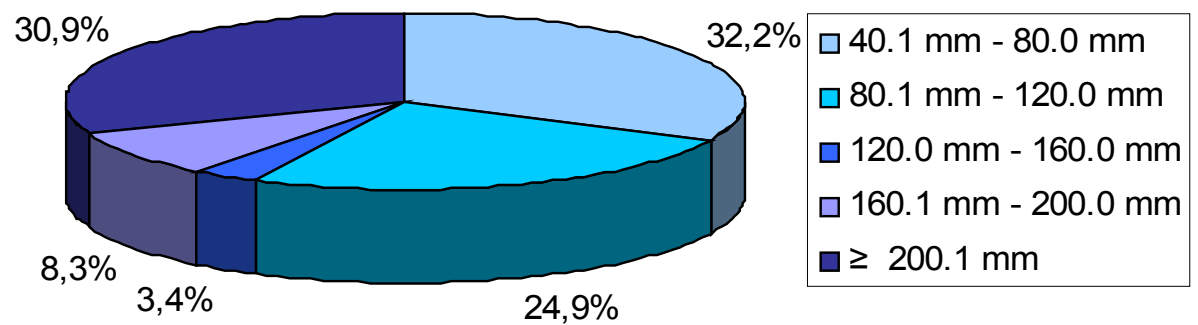

Figura 31. Freqüência acumulada dos eventos (enchentes + deslizamentos) de acordo com as de pluviometria para um período de $72 \mathrm{~h}$.

Como primeira iniciativa para a definição de índices críticos de pluviosidade (índices pluviométricos que quando atingidos indicam uma elevada probabilidade da ocorrência de deslizamentos de terra com acidentes) para caracterizar uma situação de alerta adotou-se os valores médios dos índices pluviométricos para os quais foram registrados eventos de deslizamentos e enchentes, expostos na Tabela 9. 
Tabela 9. Primeira estimativa dos índices críticos de chuva.

\begin{tabular}{|c|c|c|c|}
\hline \multirow{2}{*}{ Período analisado } & \multicolumn{3}{|c|}{$\begin{array}{r}\text { Índices pluviométricos médios referentes aos } \\
\text { eventos registrados }(\mathrm{mm})\end{array}$} \\
\cline { 2 - 4 } & Enchentes & Deslizamentos & $\begin{array}{r}\text { Enchentes + } \\
\text { Deslizamentos }\end{array}$ \\
\hline $24 \mathrm{~h}$ & 66,00 & 65,31 & 65,35 \\
\hline $48 \mathrm{~h}$ & 111,21 & 109,82 & 109,92 \\
\hline $72 \mathrm{~h}$ & 108,72 & 147,18 & 146,08 \\
\hline
\end{tabular}

Conforme citado anteriormente, os índices mais adequados para serem correlacionados com as enchentes no Município de Petrópolis deveriam ser menores que 24h. Portanto, os índices de períodos maiores (48 e 72h) não foram considerados.

Desta forma, os índices pluviométricos apresentados na Tabela 10 deverão ser adotados para a situação de alerta. A situação de alerta estará caracterizada quando qualquer um dos três índices for atingido. Ressaltamos que esses valores apresentam certo grau de incerteza, pelos motivos expostos anteriormente, sendo, portanto, meramente indicativos, devendo ser confirmados ao longo do tempo. Recomenda-se que os órgãos municipais responsáveis pelos registros dos eventos de deslizamentos e enchentes adotem uma nova metodologia de registro de dados onde deverão ser informados os horários de ocorrência dos respectivos eventos.

Tabela 10. Índices pluviométricos de situação alerta.

\begin{tabular}{|c|c|}
\hline Período analisado & $\begin{array}{c}\text { Índices pluviométricos para definir a } \\
\text { situação de alerta }(\mathrm{mm})\end{array}$ \\
\hline $24 \mathrm{~h}$ & 60 \\
\hline $48 \mathrm{~h}$ & 100 \\
\hline $72 \mathrm{~h}$ & 140 \\
\hline
\end{tabular}


3.3. Análise dos mapas hipsométrico, orientação das encostas e declividade, relacionados com a ocorrência de enchentes e deslizamentos no Bairro do Quitandinha.

A análise que se segue está apoiada nos mapas apresentados como hipsometria (Figura 32), o declividade (Figura 33) orientação das encostas (Figura 34).

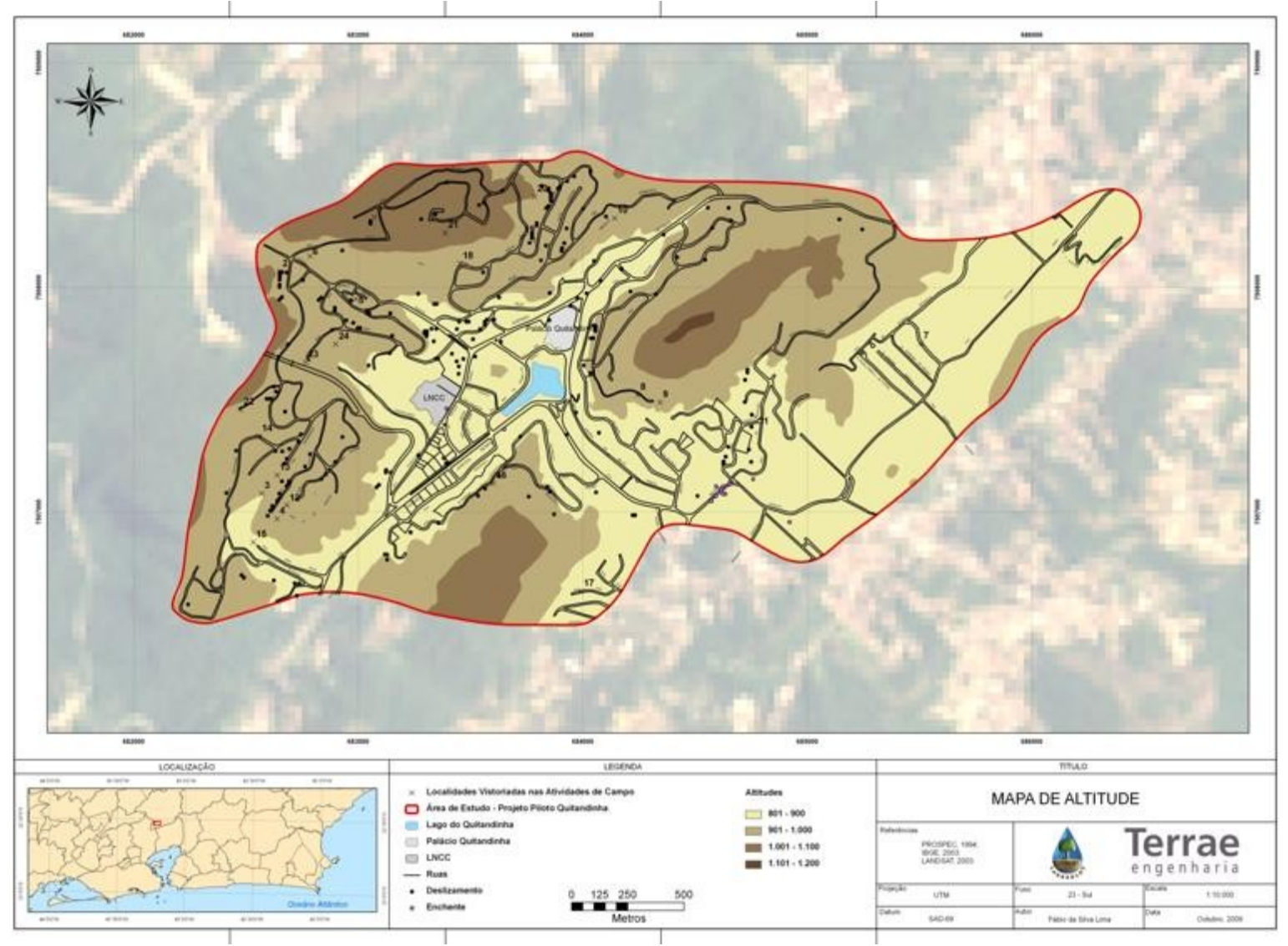

Figura 32. Mapa hipsométrico, bairro Quitandinha, Petrópolis-RJ. 


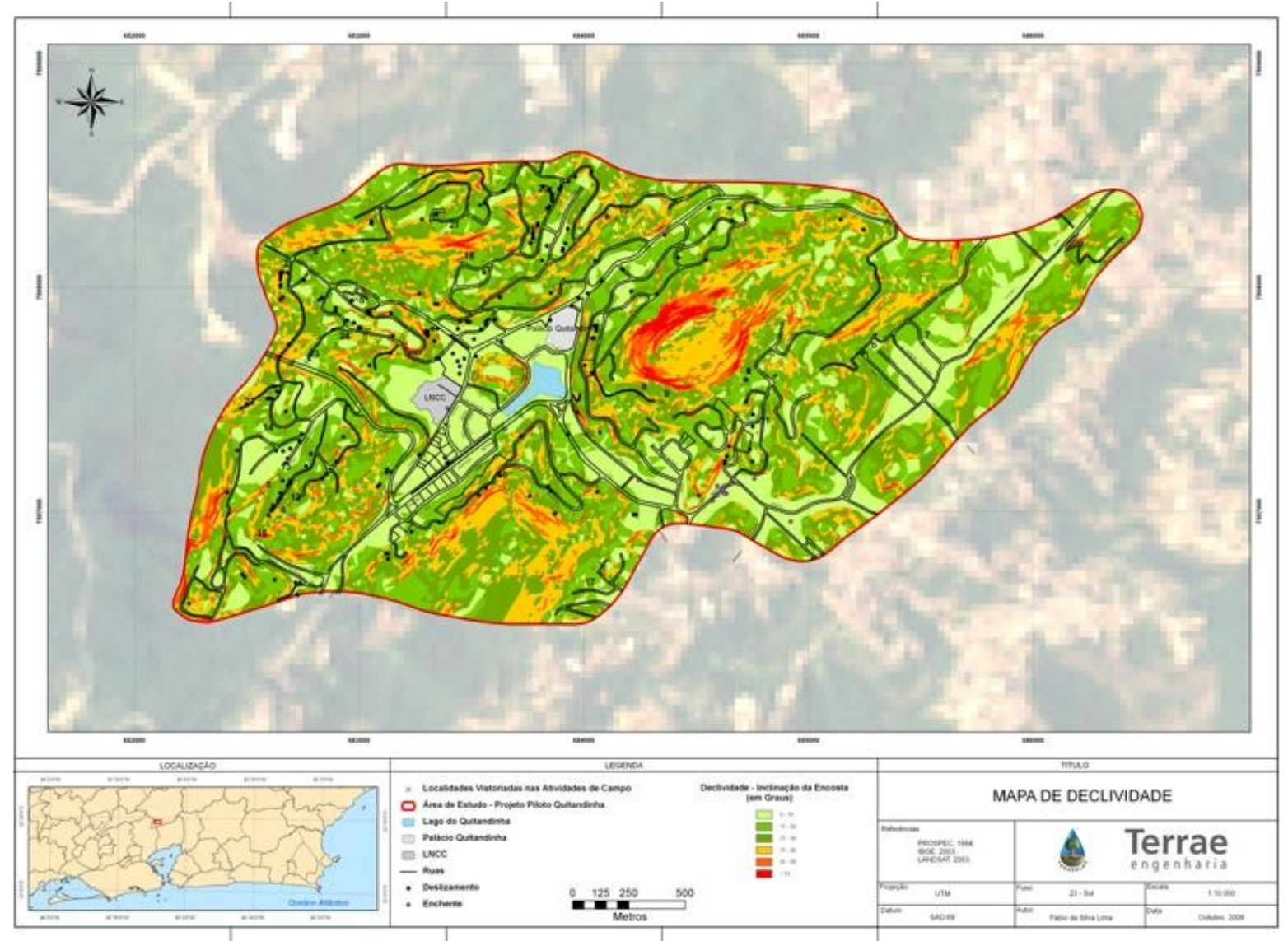

Figura 33. Mapa de declividade, bairro Quitandinha, Petrópolis-RJ 


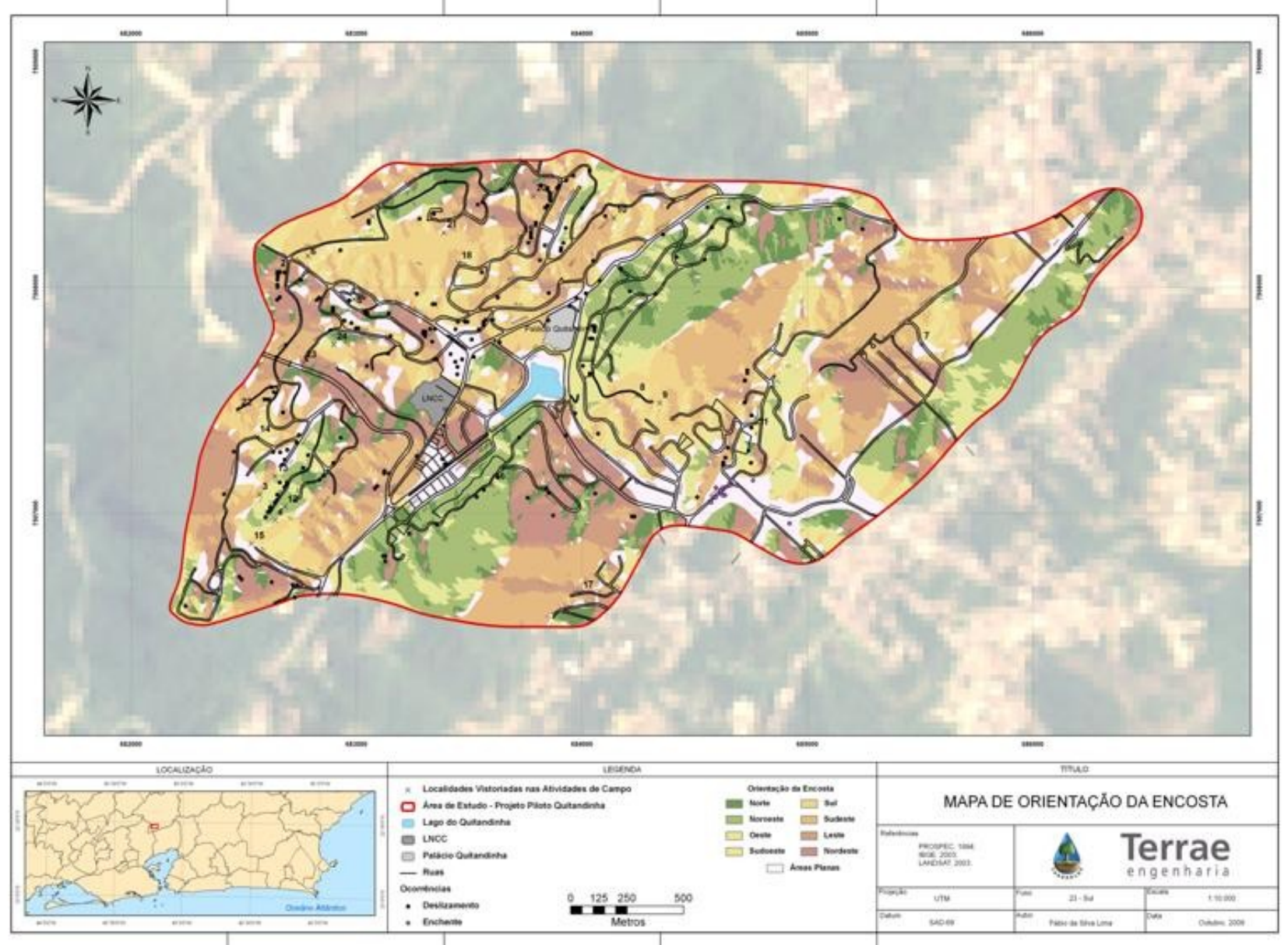

Figura 34. Mapa de orientação da encosta e enchentes, bairro Quitandinha, PetrópolisRJ.

A análise parte da compreensão dos elementos de forma separada para posterior entendimento do conjunto, ou seja, como os elementos interagem um com o outro e a influência que os mesmos exercem no contexto geral da ocorrência de enchentes e deslizamentos. O principal objetivo é examinar se poderão ser encontrados alguns padrões espaciais de distribuição de eventos catastróficos de deslizamentos e enchentes.

Numa primeira observação dos mapas, é possível identificar dois grandes padrões:

a) os deslizamentos, que apesar de se espalharem por uma vasta área do bairro do Quitandinha, predominam na porção central e a oeste;

b) a concentração de enchentes ao longo do rio Quitandinha, nas porções mais baixas, a leste da área analisada. 
Os mapas de declividade e hispométrico são uma forma de representação do relevo, pois indicam a inclinação das vertentes e a dissecação do relevo, respectivamente, e através destas variáveis é possível analisar o uso que lhe é atribuído e até mesmo planejar sua ocupação. O mapa de orientação de vertentes (Figura 34) indica a direção para a qual a vertente da encosta está voltada (Figura 35) .Esses mapas são gerados a partir do modelo digital do terreno através do software ARCGIS.
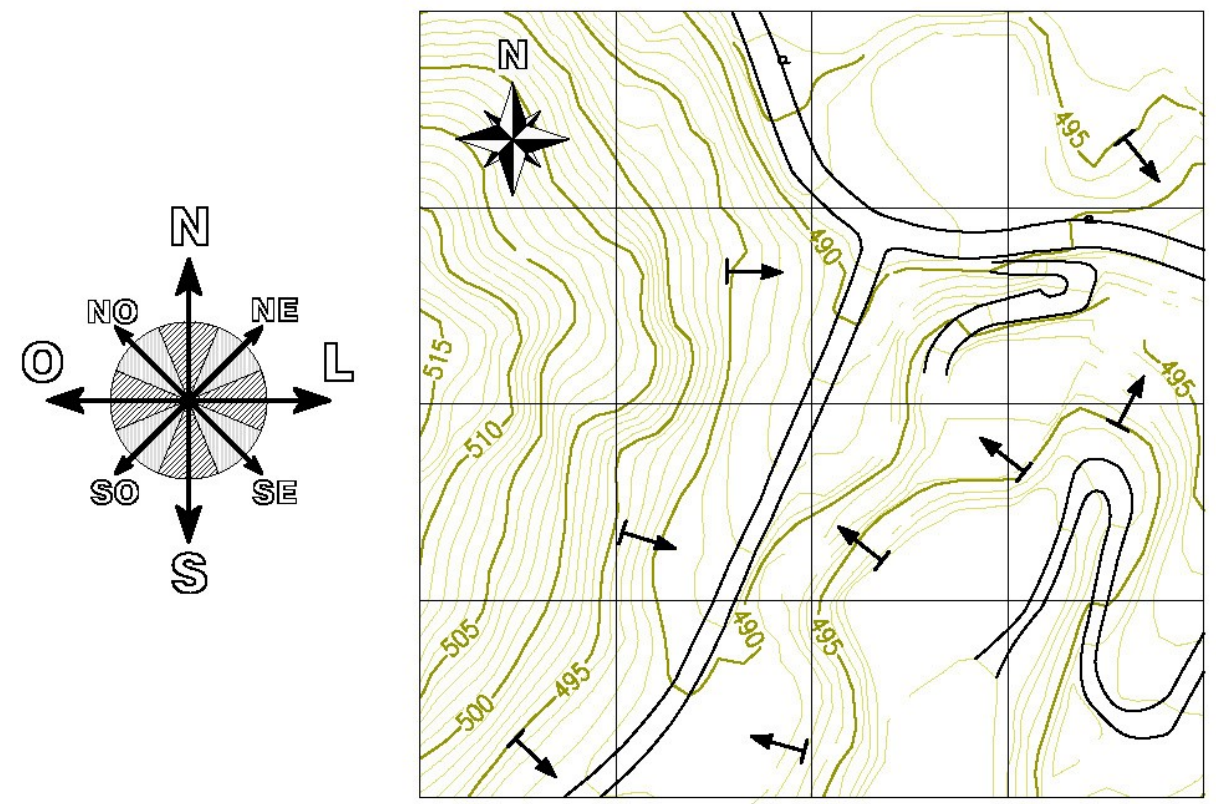

Figura 35 - Desenho esquemático com exemplos do significado da orientação de encostas.

Para a análise dos deslizamentos, o primeiro mapa que deve ser considerado é o de declividade da encosta, pois essa característica está diretamente relacionada à estabilidade do talude.

Apesar dos deslizamentos terem acontecido em todas as classes do mapa de declividade (Tabela 11), aquelas que concentram o maior número de ocorrências correspondem às classes de 11 a $20^{\circ}$ (30,28\% do total de eventos de deslizamentos) e de 21 a $30^{\circ}(27,29 \%)$. Nas classes de maiores declividades $\left(31\right.$ a $40^{\circ}, 41$ a $50^{\circ}$ e maior que 
$50^{\circ}$ ) há uma diminuição gradativa do número de deslizamentos. Mesmo na classe de $0 \mathrm{a}$ $10^{\circ}$ ocorreram $28,57 \%$ dos deslizamentos, um número bastante significativo. A maior concentração dos eventos de deslizamentos nas menores faixas de declividade (até $30^{\circ}$ ) em relação às de maior declividade pode estar relacionado a dois aspectos: a maior ocupação humana e a presença de maiores depósitos de colúvio. A elevada ocorrência de deslizamentos em terrenos de declividades muito baixas ressalta o alto poder nocivo das ações antrópicas para a estabilidade das encostas.

Correlacionando as enchentes com o mapa de declividade, como era de se esperar, a grande maioria aconteceu na classe entre 0 e $10^{\circ}(95,24 \%, 40$ eventos), que correspondem às áreas de fundo de vale, onde há uma convergência de fluxos, restando apenas dois eventos na classe de 10 a $20^{\circ}$.

Quanto à altitude predominante, esta se localiza na faixa que varia de 900 a 1000 metros $(54.60 \%)$, representando mais da metade da área total desta. Na seqüência tem-se a faixa que varia de 800 a 900 metros $(42,86$ \%), na porção inferior. Na porção mais elevada, onde são encontradas altitudes que variam de 1000 a 1200 metros, observa-se que a faixa que a representa é estreita, indicando que o índice de dissecação do terreno é alto e, conseqüentemente, ocorrem as altas declividades.

No que diz respeito à correlação entre os deslizamentos e a hipsometria, 59,49\% dos eventos ocorreram na classe de 900 a 1.000 metros de altitude, sendo um número menor na classe de 800 a 900 metros, $37,74 \%$, restando apenas $2,77 \%$ na classe de 1.000 a 1.100 metros.

Quanto às enchentes, quando relacionadas ao mapa hipsométrico, todas as ocorrências aconteceram como era de se esperar, na menor classe, de 800 a 900 metros de altitude, que correspondem às convergências de fluxos nas regiões de fundo de vale.

Quanto à orientação das encostas, não foi identificado nenhum padrão significativamente predominante de ocorrências, uma vez que os deslizamentos se disseminaram por todas as orientações, com percentuais que variaram de 5,12\% (Norte) a 18,98\% (Sudeste). Vale informar, entretanto, que houve uma leve predominância de deslizamentos nas encostas com orientação entre as direções sul e nordeste. 
Tabela 11. Distribuição de ocorrências segundo as classes de altitude, declividade e orientação das vertentes.

\begin{tabular}{|c|c|c|}
\hline \multicolumn{3}{|c|}{ GERAL } \\
\hline & $\begin{array}{l}\text { Núme- } \\
\text { ro }\end{array}$ & $\begin{array}{l}\text { Porcenta- } \\
\text { gem }\end{array}$ \\
\hline $\begin{array}{l}\text { Total de } \\
\text { Ocorrências }\end{array}$ & 511 & $100,00 \%$ \\
\hline \multicolumn{3}{|l|}{ Altitude (m) } \\
\hline $800-900$ & 219 & $42,86 \%$ \\
\hline $900-1000$ & 279 & $54,60 \%$ \\
\hline $1000-1100$ & 13 & $2,54 \%$ \\
\hline $1100-1200$ & $\mathrm{~N} / \mathrm{O}$ & $0,00 \%$ \\
\hline \multicolumn{3}{|l|}{ Orientação } \\
\hline Áreas Planas & 125 & $24,46 \%$ \\
\hline Norte & 25 & $4,89 \%$ \\
\hline Nordeste & 58 & $11,35 \%$ \\
\hline Leste & 38 & $7,44 \%$ \\
\hline Sudeste & 89 & $17,42 \%$ \\
\hline Sul & 61 & $11,94 \%$ \\
\hline Sudoeste & 13 & $2,54 \%$ \\
\hline Oeste & 67 & $13,11 \%$ \\
\hline Noroeste & 35 & $6,85 \%$ \\
\hline \multicolumn{3}{|l|}{ Declividade } \\
\hline $0-10$ & 146 & $28,57 \%$ \\
\hline $11-20$ & 144 & $28,18 \%$ \\
\hline $21-30$ & 128 & $25,05 \%$ \\
\hline $31-40$ & 73 & $14,29 \%$ \\
\hline $41-50$ & 16 & $3,13 \%$ \\
\hline$>51$ & 4 & $0,78 \%$ \\
\hline
\end{tabular}

\begin{tabular}{|c|c|c|}
\hline \multicolumn{3}{|c|}{ SÓ PARA ENCHENTE } \\
\hline & $\begin{array}{c}\text { Núme- } \\
\text { ro }\end{array}$ & Porcentagem \\
\hline Enchente & 42 & $8,22 \%$ \\
\hline \multicolumn{3}{|l|}{ Altitude (m) } \\
\hline $800-900$ & 42 & $100,00 \%$ \\
\hline $900-1000$ & $\mathrm{~N} / \mathrm{O}$ & $0,00 \%$ \\
\hline $1000-1100$ & $\mathrm{~N} / \mathrm{O}$ & $0,00 \%$ \\
\hline $1100-1200$ & $\mathrm{~N} / \mathrm{O}$ & $0,00 \%$ \\
\hline \multicolumn{3}{|l|}{ Orientação } \\
\hline Áreas Planas & 39 & $92,86 \%$ \\
\hline Norte & 1 & $2,38 \%$ \\
\hline Nordeste & $\mathrm{N} / \mathrm{O}$ & $0,00 \%$ \\
\hline Leste & $\mathrm{N} / \mathrm{O}$ & $0,00 \%$ \\
\hline Sudeste & $\mathrm{N} / \mathrm{O}$ & $0,00 \%$ \\
\hline Sul & 1 & $2,38 \%$ \\
\hline Sudoeste & $\mathrm{N} / \mathrm{O}$ & $0,00 \%$ \\
\hline Oeste & $\mathrm{N} / \mathrm{O}$ & $0,00 \%$ \\
\hline Noroeste & 1 & $2,38 \%$ \\
\hline \multicolumn{3}{|l|}{ Declividade } \\
\hline $0-10$ & 40 & $95,24 \%$ \\
\hline $11-20$ & 2 & $4,76 \%$ \\
\hline $21-30$ & $\mathrm{~N} / \mathrm{O}$ & $0,00 \%$ \\
\hline $31-40$ & $\mathrm{~N} / \mathrm{O}$ & $0,00 \%$ \\
\hline $41-50$ & $\mathrm{~N} / \mathrm{O}$ & $0,00 \%$ \\
\hline$>51$ & $\mathrm{~N} / \mathrm{O}$ & $0,00 \%$ \\
\hline
\end{tabular}

\begin{tabular}{|c|c|c|}
\hline \multicolumn{3}{|c|}{ SÓ PARA DESLIZAMENTO } \\
\hline & Número & Porcentagem \\
\hline Deslizamento & 469 & $91,78 \%$ \\
\hline \multicolumn{3}{|l|}{ Altitude (m) } \\
\hline $800-900$ & 177 & $37,74 \%$ \\
\hline $900-1000$ & 279 & $59,49 \%$ \\
\hline $1000-1100$ & 13 & $2,77 \%$ \\
\hline $1100-1200$ & $\mathrm{~N} / \mathrm{O}$ & $0,00 \%$ \\
\hline \multicolumn{3}{|l|}{ Orientação } \\
\hline Áreas Planas & 86 & $18,34 \%$ \\
\hline Norte & 24 & $5,12 \%$ \\
\hline Nordeste & 58 & $12,37 \%$ \\
\hline Leste & 38 & $8,10 \%$ \\
\hline Sudeste & 89 & $18,98 \%$ \\
\hline Sul & 60 & $12,79 \%$ \\
\hline Sudoeste & 13 & $2,77 \%$ \\
\hline Oeste & 67 & $14,29 \%$ \\
\hline Noroeste & 34 & $7,25 \%$ \\
\hline \multicolumn{3}{|l|}{ Declividade } \\
\hline $0-10$ & 106 & $22,60 \%$ \\
\hline $11-20$ & 142 & $30,28 \%$ \\
\hline $21-30$ & 128 & $27,29 \%$ \\
\hline $31-40$ & 73 & $15,57 \%$ \\
\hline $41-50$ & 16 & $3,41 \%$ \\
\hline$>51$ & 4 & $0,85 \%$ \\
\hline
\end{tabular}

Quanto à altitude predominante, esta se localiza na faixa que varia de 900 a 1000 metros $(54.60 \%)$, representando mais da metade da área total desta. Na seqüência tem-se a faixa que varia de 800 a 900 metros $(42,86$ \%), na porção inferior. Na porção mais elevada, onde são encontradas altitudes que variam de 1000 a 1200 metros, observa-se 
que a faixa que a representa é estreita, indicando que o índice de dissecação do terreno é alto e, conseqüentemente, ocorrem as altas declividades.

No que diz respeito à correlação entre os deslizamentos e a hipsometria, 59,49\% dos eventos ocorreram na classe de 900 a 1.000 metros de altitude, sendo um número menor na classe de 800 a 900 metros, $37,74 \%$, restando apenas $2,77 \%$ na classe de 1.000 a 1.100 metros.

Quanto às enchentes, quando relacionadas ao mapa hipsométrico, todas as ocorrências aconteceram como era de se esperar, na menor classe, de 800 a 900 metros de altitude, que correspondem às convergências de fluxos nas regiões de fundo de vale.

Quanto à orientação das encostas, não foi identificado nenhum padrão significativamente predominante de ocorrências, uma vez que os deslizamentos se disseminaram por todas as orientações, com percentuais que variaram de 5,12\% (Norte) a 18,98\% (Sudeste). Vale informar, entretanto, que houve uma leve predominância de deslizamentos nas encostas com orientação entre as direções sul e nordeste.

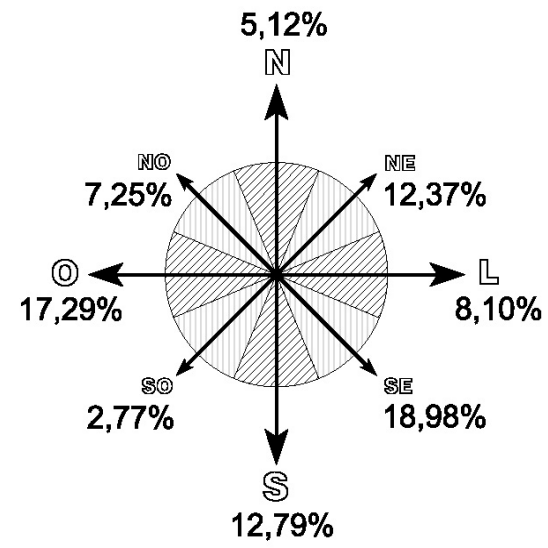

Observação: O percentual ao lado refere-se ao total de eventos de deslizamentos, sendo que $18,34 \%$ não estão apresentados nesta figura porque, segundo a localização no mapa de declividade ocorreram em áreas planas. Portanto, o desenho ao lado apresenta um total de $81.66 \%$.

Figura 36 - Percentual dos eventos de deslizamentos.

A indicação no mapa da área de ocorrência de enchentes é importante para a Defesa Civil, no sentido desta atuar preventivamente. Esse mapa mostra claramente, de acordo com a altitude, até onde as enchentes podem atingir.

É claro que outras variáveis podem ser utilizadas no diagnóstico e prognóstico de deslizamentos e enchentes. No entanto, para esse estudo, foram selecionadas apenas 
Anais II Seminário de Recursos Hídricos da Bacia Hidrográfica do Paraíba do Sul: Recuperação de Áreas Degradadas, Serviços Ambientais e Sustentabilidade, Taubaté, Brasil, 09-11 dezembro 2009, IPABHi, p. 785-824.

aquelas aqui listadas, já que são consideradas altamente relevantes pela literatura geomorfológica, nacional e internacional.

\section{CONCLUSÕES}

Pelo que foi apresentado nesse artigo, pode-se concluir, que os conhecimentos geomorfológicos, pedológicos, geotécnicos e geológicos, quando analisados em conjunto, podem ser de grande valia, no diagnóstico e prognóstico de áreas sujeitas à ocorrência de deslizamentos de terra e de enchentes, o que sem dúvida é fundamental, para que a Defesa Civil de qualquer município possa atuar preventivamente.

O trabalho também demonstrou que é necessário existir uma série histórica de eventos catastróficos que já tenham ocorrido na área estudada, bem como dados relativos aos totais pluviométricos diários, referentes ao mesmo período da ocorrência desses eventos catastróficos. Caso contrário fica praticamente impossível chegar-se aos resultados aqui apresentados.

Os resultados aqui apresentados poderão oferecer à Defesa Civil, em tempo real, quais os riscos de deslizamentos e de enchentes, para cada bairro do município, ou para cada área do município, baseado, nas informações relativas ao quadro natural, bem como a atuação do homem, que ficam bem caracterizados nas vistorias realizadas, durante a execução desse trabalho. A partir disso, os agentes da Defesa Civil podem sair a campo, com uma margem de probabilidade de acerto bem elevada, no sentido de remover pessoas de suas casas, que estejam na iminência do risco de acontecer um deslizamento e/ou uma enchente.

Esperamos, com esse estudo, ter demonstrado que é possível, com levantamentos de campo e de gabinete, e com a participação de um grupo multidisciplinar, propor uma metodologia e testá-la, para que seja possível um trabalho conjunto entre pesquisadores das universidades e técnicos da prefeitura, no sentido de podermos atuar diretamente sobre problemas que muitas municipalidades brasileiras sofrem, em especial aqueles que dizem respeito aos riscos de deslizamentos e de enchentes, que têm causado a perda de tantas vidas humanas, bem como de danos materiais. 


\section{REFERÊNCIA BIBLIOGRÁFICA}

CHRISTOFOLETTI, A. (2001). Aplicabilidade do conhecimento geomorfológico nos projetos de planejamento. In: Geomorfologia: uma atualização de bases e conceitos. Organizadores: A.J.T. Guerra e S.B. Cunha, Ed. Bertrand Brasil, 4 4 edição, 415-440.

CUNHA, S. B. e GUERRA, A. J. T. 2006. Degradação ambiental. In: Geomorfologia e meio ambiente. Editora Bertrand Brasil, $2^{\mathrm{a}}$ ed, p. 337-376.

GONÇALVES, L. F. G. e GUERRA, A.J.T. (2009). Movimentos de Massa na cidade do Rio de Petrópolis (Rio de Janeiro). In: Impactos Ambientais Urbanos no Brasil. Organizadores: A.J.T. Guerra e S.B. Cunha, Ed. Bertrand Brasil, $5^{\text {a }}$ edição, 189-252.

GUERRA, A.J.T. e MENDONÇA, J.K.S. (2004). Erosão dos solos e a questão ambiental. In: Reflexões sobre a Geografia Física no Brasil. Organizadores: A.C. Vitte e A.J.T. Guerra, Ed. Bertrand Brasil, 226-256.

GUERRA, A., OLIVEIRA, A, OLIVEIRA, F. e GONÇALVES, L. (2007). Mass movements in Petrópolis, Brazil. Geography Review, volume 20, 4, 34-37.

GUERRA, A. J. T . e LOPES, P.B.M. (2009). APA de Petrópolis: um estudo das Características Geográficas. In: Unidades de Conservação - Abordagens e Características Geográficas. Organizadores: A.J.T. Guerra e M.C.N. Coelho, Ed. Bertrand Brasil, 113141.

MENDONÇA, M. B. e TEMÓTEO, J.P.S. 1993. Observações sobre Intervenções em Áreas de Risco Geológico-Geotécnico em Petrópolis, RJ, Anais COPPEGEO'93, Rio de Janeiro, pp.173-179.

MENDONÇA, M. B. e GUERRA, A.T (1997). A Problemática dos Processos Geodinâmicos frente à Ocupação Encostas, Anais 2nd Panamerican Symposium on Landslides, Rio de Janeiro, vol. 2, pp.935-940. 
RADAM BRASIL. Secretaria Geral 1983. Ministério de Minas e Energia. Projeto Radam Brasil. Rio de Janeiro/Vitória. V. 32.

Relatórios do Projeto "Prevenção de Calamidades por Intempéries" - Desenvolvimento do Protótipo de um Sistema de Previsão e Alerta ao Risco de Enchentes e Escorregamentos de Encostas no Município de Petrópolis (5 relatórios encaminhados à SEA e ao LNCC, entre setembro de 2008 e novembro de 2009), realizados pela equipe de Geotecnia e Geomorfologia do Referido Projeto.

SELBY, M.J. (1993). Hillslope Materials and Processess. Oxford, Oxford University Press, $2^{\mathrm{a}}$ edição, $451 \mathrm{p}$. 